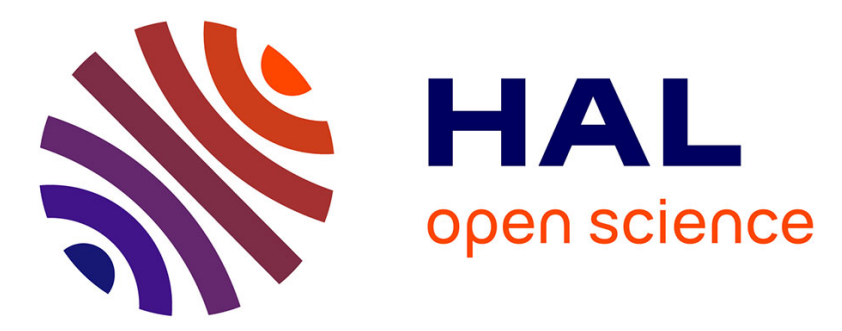

\title{
Observations of the 11 June Dryline during IHOP_2002-A Null Case for Convection Initiation
}

Huaqing Cai, Wen-Chau Lee, Tammy M. Weckwerth, Cyrille Flamant, Hanne V. Murphey

\section{- To cite this version:}

Huaqing Cai, Wen-Chau Lee, Tammy M. Weckwerth, Cyrille Flamant, Hanne V. Murphey. Observations of the 11 June Dryline during IHOP_2002-A Null Case for Convection Initiation. Monthly Weather Review, 2006, 134, pp.336-354. 10.1175/MWR2998.1 . hal-00068815

\section{HAL Id: hal-00068815 https://hal.science/hal-00068815}

Submitted on 18 Jul 2020

HAL is a multi-disciplinary open access archive for the deposit and dissemination of scientific research documents, whether they are published or not. The documents may come from teaching and research institutions in France or abroad, or from public or private research centers.
L'archive ouverte pluridisciplinaire HAL, est destinée au dépôt et à la diffusion de documents scientifiques de niveau recherche, publiés ou non, émanant des établissements d'enseignement et de recherche français ou étrangers, des laboratoires publics ou privés. 


\title{
Observations of the 11 June Dryline during IHOP_2002-A Null Case for Convection Initiation
}

\author{
Huaqing CAI
}

Advanced Study Program and Atmospheric Technology Division, National Center for Atmospheric Research, Boulder, Colorado

Wen-Chau Lee and Tammy M. Weckwerth

Atmospheric Technology Division, National Center for Atmospheric Research, Boulder, Colorado

Cyrille Flamant

Institut Pierre-Simon Laplace/Service d'Aeronomie, Paris, France

HANNE V. MuRPhey

Department of Atmospheric Sciences, University of California, Los Angeles, Los Angeles, California

(Manuscript received 16 August 2004, in final form 1 March 2005)

\begin{abstract}
The detailed analysis of the three-dimensional structure of a dryline observed over the Oklahoma panhandle during the International $\mathrm{H}_{2} \mathrm{O}$ Project (IHOP_2002) on 11 June 2002 is presented. High-resolution observations obtained from the National Center for Atmospheric Research Electra Doppler Radar (ELDORA), S-band dual-polarization Doppler radar (S-Pol), water vapor differential absorption lidar (DIAL) Lidar pour l'Etude des Interactions Aérosols Nuages Dynamique Rayonnement et du Cycle de l'Eau (LEANDRE II; translated as Lidar for the Study of Aerosol-Cloud-Dynamics-Radiation Interactions and of the Water Cycle) as well as Learjet dropsondes are used to reveal the evolution of the dryline structure during late afternoon hours when the dryline was retreating to the northwest. The dryline reflectivity shows significant variability in the along-line direction. Dry air was observed to overrun the moist air in vertical cross sections similar to a density current. The updrafts associated with the dryline were $2-3 \mathrm{~m} \mathrm{~s}^{-1}$ and were able to initiate boundary-layer-based clouds along the dryline. The formation of this dryline was caused by high equivalent potential temperature air pushing northwestward toward a stationary front in the warm sector.

Middle-level clouds with radar reflectivity greater than $18 \mathrm{~dB} Z_{\mathrm{e}}$ near the dryline were detected by ELDORA. A roll boundary, which was associated with larger convergence and moisture content, was evident in the S-Pol data. It is found that the instability parameters most favorable for convection initiation were actually associated with the roll boundary, not the dryline. A storm was initiated near the roll boundary probably as a result of the combination of the favorable instability parameters and stronger upward forcing. It is noted that both the 11 June 2002 dryline and the roll boundary presented in this paper would not be identified if the special datasets from IHOP_2002 were not available.

Although all model runs [fifth-generation Pennsylvania State University-NCAR Mesoscale Model (MM5), Meso Eta, and Rapid Update Cycle (RUC)] suggested deep convection over the Oklahoma panhandle and several cloud lines were observed near the dryline, the dryline itself did not initiate any storms. The reasons why the dryline failed to produce any storm inside the IHOP_2002 intensive observation region are discussed. Both synoptic-scale and mesoscale conditions that were detrimental to convection initiation in this case are investigated in great detail.
\end{abstract}

Corresponding author address: Huaqing Cai, Advanced Study Program and Atmospheric Technology Division, National Center for Atmospheric Research, Boulder, CO 80307.

E-mail: caihq@ucar.edu 


\section{Introduction}

During spring and early summer, hot dry air flowing off the semiarid plateau regions of Mexico and the southwest United States meets cooler moist air originating from the Gulf of Mexico, forming a boundary called the dryline (Rhea 1966; Schaefer 1974, 1986). The dryline is a relatively common feature that occurs $\sim 40 \%$ of the time over the Great Plains in late spring and early summertime and has been studied extensively owing to its important role in convection initiation (e.g., Schaefer 1974; Anthes et al. 1982; Koch and McCarthy 1982; Bluestein and Parks 1983; Bluestein and Parker 1993; Parsons et al. 1991, 2000; Sun and Wu 1992; Ziegler and Hane 1993; Ziegler et al. 1995; Hane et al. 1993, 1997, 2001, 2002; Shaw et al. 1997; Atkins et al. 1998; Grasso 2000; Peckham and Wicker 2000; Miller et al. 2001; Weiss and Bluestein 2002; Trier et al. 2004). The structure of the dryline has been documented using various observational tools such as surface mesonets, mobile soundings, aircraft in situ measurements (e.g., Ziegler and Hane 1993; Hane et al. 1993, 1997, 2001, 2002), Doppler lidar (Parsons et al. 1991), and airborne Doppler radar with clear-air capability (Atkins et al. 1998; Weiss and Bluestein 2002).

Although drylines are favorable places for convection initiation, not every dryline initiates storms. There have been a few hypotheses trying to explain why convection does not initiate even though the dryline itself seems to provide enough upward lift. In a case analyzed by Weiss and Bluestein (2002), they argued that a dry layer between the lifting condensation level (LCL) and the level of free convection (LFC) just atop of the convective boundary layer (CBL) played a key role in prohibiting convection initiation. When moist boundary layer updrafts enter this very dry layer, entrainment and evaporation will occur and eventually the updraft will lose its buoyancy. Richter and Bosart (2002) studied the synoptic-scale environment of a dryline during the Verification of Origins of Rotation in Tornadoes Experiment (VORTEX 95) and found that a shortwave ridge over the dryline region caused mesoscale subsidence and warming at the middle levels, which prevented convection initiation on that particular day even though earlier forecasts suggested that severe storms would be likely. Another detrimental factor for convection initiation associated with drylines is strong shear within the boundary layer. Ziegler and Rasmussen (1998) suggested that strong shear enhances entrainment and turbulent mixing and as a result of that the updraft will be diluted and becomes much weaker.

On 11 June 2002 during the International $\mathrm{H}_{2} \mathrm{O}$ Project (IHOP_2002; Weckwerth et al. 2004), a dryline formed in the Oklahoma panhandle in the late afternoon and was retreating to the northwest at a speed of 1.5-2.5 $\mathrm{m} \mathrm{s}^{-1}$. All the IHOP_2002 facilities were directed to the region in hope of deep convection based on early model forecasting. Nevertheless, convection did not initiate despite the fact that all models [fifthgeneration Pennsylvania State University-National Center for Atmospheric Research (Penn State-NCAR Mesoscale Model (MM5), Meso Eta, and Rapid Update Cycle (RUC)] suggested convection initiation over the Oklahoma panhandle (see the IHOP_2002 field catalog at http://www.joss.ucar.edu/ihop/catalog/ missions.html). Although no convection was initiated near the dryline inside the IHOP_2002 intensive observation region [IOR; defined as the dual-Doppler domain of the Electra Doppler Radar (ELDORA)], three storms were initiated outside the IHOP_2002 IOR. One tornadic storm (storm A) was initiated along a stationary front near Russell, Kansas, which was $\sim 200$ $\mathrm{km}$ northeast of IHOP_2002 IOR. The second smaller storm (storm B) was initiated along the stationary front $\sim 100 \mathrm{~km}$ north of IHOP_2002 IOR. The third storm (storm C) was initiated along a preexisting fine line, which probably originated from well-defined horizontal convective rolls (HCRs; hereafter, this boundary will be called the roll boundary) $\sim 80 \mathrm{~km}$ south of the IHOP_2002 IOR (see Fig. 1).

This paper documents the detailed structure and evolution of the 11 June dryline using ELDORA (Hildebrand et al. 1994, 1996), S-band dual-polarization Doppler radar (S-Pol) (Lutz et al. 1995), the water vapor differential absorption lidar (DIAL) Lidar pour l'Etude des Interactions Aérosols Nuages Dynamique Rayonnement et du Cycle de l'Eau (LEANDRE II; translated as Lidar for the Study of Aerosol-CloudDynamics-Radiation Interactions and of the Water Cycle) (Bruneau et al. 2001), Learjet dropsondes (Hock and Franklin 1999), NCAR Mobile GPS/Loran Atmospheric Sounding System (MGLASS) soundings (Bluestein 1993), as well as Naval Research Laboratory (NRL) P-3 flight-level data. The S-Pol radar refractivity for mapping surface moisture, the water vapor measurements by LEANDRE II, and Learjet dropsondes for constructing the mesoscale environment of the dryline are unique to IHOP_2002 studies since they were not available before IHOP_2002. One novel observation that came out of this paper is the simultaneous detection of the dryline and middle-level clouds by ELDORA that had yet to be accomplished in previous dryline studies. National Centers for Environmental Prediction (NECP)-NCAR reanalysis data (Kalnay et al. 1996; Kistler et al. 2001) are used to investigate the synoptic-scale environment at middle 

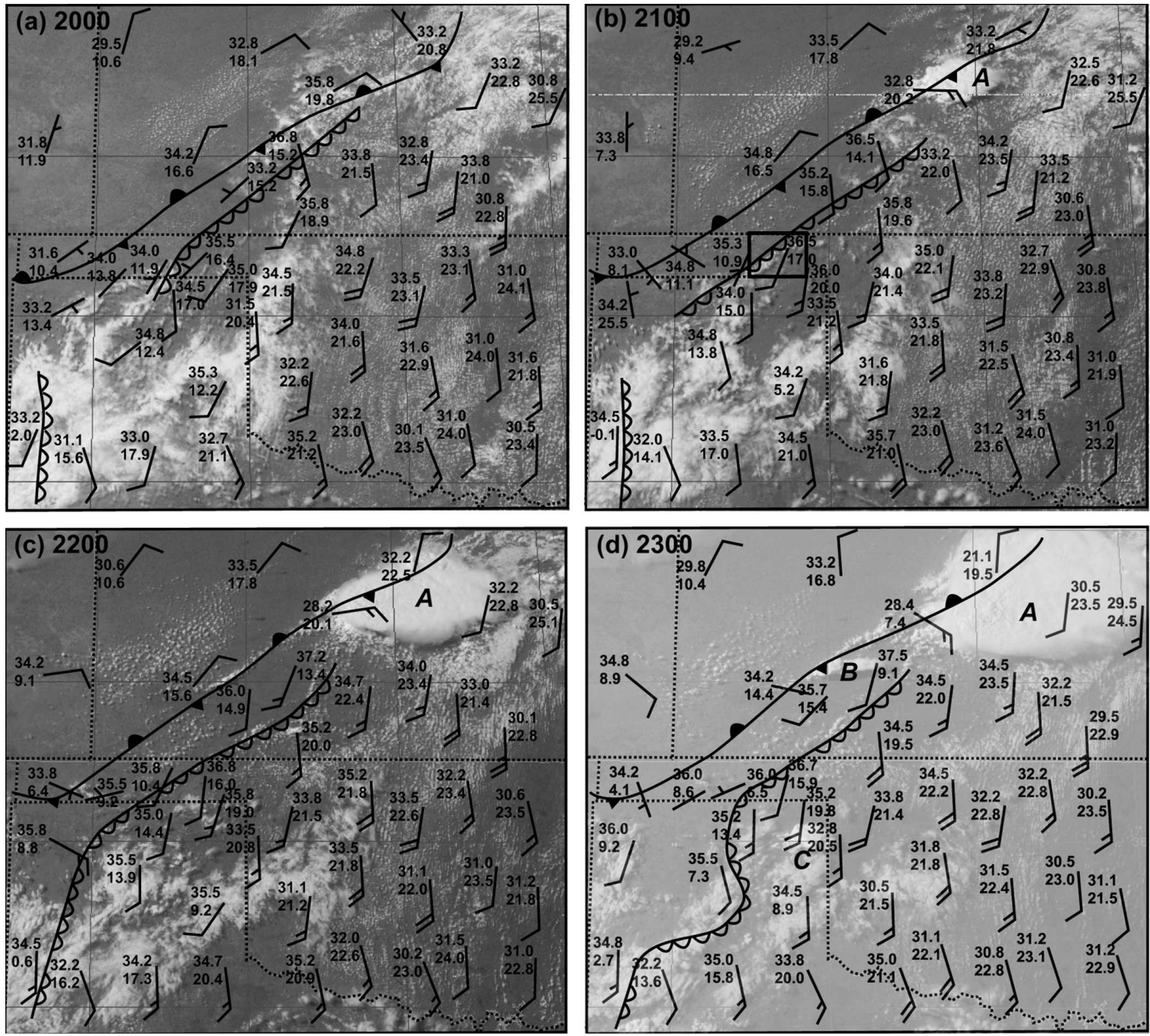

FIG. 1. Subjective surface analyses superimposed onto visible satellite images at (a) 2000, (b) 2100, (c) 2200, and (d) 2300 UTC on 11 Jun 2002. Temperature and dewpoint temperature are shown $\left({ }^{\circ} \mathrm{C}\right)$. Wind vectors are plotted with full barb and half barb representing 5 and $2.5 \mathrm{~m} \mathrm{~s}^{-1}$, respectively. The black box in (b) represents the approximate dimension and position of the S-Pol and ELDORA analysis domain (i.e., the IHOP_2002 IOR) for this case.

levels over the dryline. Various factors that may affect convection initiation along the dryline are also discussed.

Section 2 briefly describes the IHOP_2002 project and data methodology. Environmental conditions and S-Pol observations are presented in sections 3 and 4, respectively. ELDORA and LEANDRE II, as well as Learjet dropsonde analyses, are respectively discussed in sections 5 and 6 . Factors not favorable for convection initiation in this case are discussed in section 7 , and a summary and discussion are presented in section 8.

\section{IHOP_2002 and data methodology}

IHOP_2002 is a multiagency field campaign involving scientists from numerous countries. It was con- ducted over the southern Great Plains in spring and early summer of 2002 (Weckwerth et al. 2004). The major objective of IHOP_2002 is to improve the understanding of the role of water vapor in various atmospheric processes such as convection initiation (CI). Both ground-based and airborne state-of-the-art remote sensing technologies are used to monitor the three-dimensional kinematic and thermodynamic variations of the atmosphere in unprecedented high spatial and temporal resolution. It is hoped that these highresolution observations that were largely unavailable before IHOP_2002 will help to further understanding of where and when convection will initiate. For an overview of IHOP_2002, please refer to Weckwerth et al. (2004). The major instruments used in this study are discussed below. 


\section{a. S-Pol radar refractivity}

The S-Pol radar developed and operated by NCAR has the unique capability to map atmospheric surface moisture fields by measuring the atmospheric refractive index, N. The basic principle is to detect the phase shift of fixed ground targets such as electrical poles and derive the atmospheric refractive index $\mathrm{N}$ from the Doppler phase shift (Fabry et al. 1997). In the summertime conditions of the atmosphere near the ground, the refractive index $\mathrm{N}$ is more sensitive to moisture than other atmospheric-state variables such as pressure and temperature; therefore the derived $\mathrm{N}$ value is a good indicator of the moisture content in the atmosphere near the ground. For details of radar-mapping surface moisture using radar refractivity, the reader is referred to Fabry et al. (1997) and Weckwerth et al. (2005).

Fortunately the dryline on 11 June 2002 during IHOP_2002 was fairly close to the S-Pol radar (less than $30 \mathrm{~km}$ ), and accurate refractivity data were collected from the dryline. Both S-Pol radar reflectivity and refractivity are interpolated on the same Cartesian coordinate system as the one used in the ELDORA dual-Doppler analysis. The horizontal grid spacing was $600 \mathrm{~m}$ and a Cressman filter with a radius of influence of $600 \mathrm{~m}$ was used in the interpolation process.

\section{b. ELDORA}

ELDORA has been successfully used in a number of field campaigns studying various atmospheric phenomena including tornadoes, supercells, fronts, and drylines (Wakimoto et al. 1996, 1998; Atkins et al. 1998; Wakimoto and Cai 2000, 2002; Dowell and Bluestein 2002a,b; Weiss and Bluestein 2002). One unique feature of ELDORA is its high sensitivity $\left(-12 \mathrm{dBZ}_{\mathrm{e}}\right.$ at $10-\mathrm{km}$ range) capable of detecting clear-air returns in the convective boundary layer that is not available to other X-band airborne Doppler radars. This capability is essential for detecting the dryline owing to the dryline's weak reflectivity. The scanning parameters for this case are listed in Table 1. A careful navigation correction was applied to the original radar data (Lee et

TABLE 1. ELDORA scanning mode.

\begin{tabular}{lc}
\hline \hline Antenna rotation rate $\left({ }^{\circ} \mathrm{s}^{-1}\right)$ & 75 \\
No. of samples & 60 \\
PRF $(\mathrm{Hz})$ & 3000 \\
Gate length $(\mathrm{m})$ & 110 \\
Sweep-angle resolution $\left({ }^{\circ}\right)$ & 1.5 \\
Along-track resolution $(\mathrm{m})$ & $\sim 550$ \\
Maximum range $(\mathrm{km})$ & 50 \\
Maximum unambiguous velocities $\left( \pm \mathrm{m} \mathrm{s}^{-1}\right)$ & 23.4 \\
\hline
\end{tabular}

al. 1994; Testud et al. 1995), and each sweep was manually edited using NCAR SOLO software (Oye at al. 1995) to remove spurious echoes such as ground clutter, sidelobes, and second trip echoes.

The along-track resolution of $\sim 550 \mathrm{~m}$ and the sweep angle resolution of $\sim 1.5^{\circ}$ determined the horizontal grid spacing of $600 \mathrm{~m}$ and vertical grid spacing of $300 \mathrm{~m}$, respectively. Accordingly, the fore and aft radar data were interpolated to a Cartesian grid using NCAR REORDER software. Only features with wavelengths larger than $3.6 \mathrm{~km}$ are resolvable in the present study based on Carbone et al. (1985). A Cressman (1959) filter is used in the interpolation process with a radius of influence of $600 \mathrm{~m}$ in the horizontal and $300 \mathrm{~m}$ in the vertical directions. Custom Editing and Display of Reduced Information in Cartesian Space (CEDRIC; Mohr et al. 1986) was used to synthesize the dualDoppler winds, and a two-step Leise (1982) filter was applied to the derived wind field. Vertical velocity was obtained by upward integration of the continuity equation. This very same dual-Doppler technique has been used in a number of ELDORA data analyses (Wakimoto et al. 1998; Atkins et al. 1998; Wakimoto and Cai 2000, 2002; Dowell and Bluestein 2002a,b; Weiss and Bluestein 2002). For details of ELDORA, the reader is referred to Hildebrand et al. $(1994,1996)$.

\section{c. LEANDRE II}

LEANDRE II is a water vapor DIAL developed at the Service d'Aéronomie [Centre National de la Recherche Scientifique (CNRS)] in cooperation with the Technical Division of the Institut National des Sciences de l'Univers (INSU) and was funded by the Centre National d'Etudes Spatiales (CNES). The design of the LEANDRE II system and the standard DIAL signal processing are discussed in great detail by Bruneau et al. (2001). The reader is referred to Murphey et al. (2006) for the configuration and characteristics of LEANDRE II during IHOP_2002.

LEANDRE II was mounted on the same aircraft (NRL P-3) as ELDORA during IHOP_2002. The lidar was pointing horizontally out of the right side of the aircraft during convection initiation missions. According to Bruneau et al. (2001), LEANDRE II has an along-beam resolution of $300 \mathrm{~m}$ and water vapor mixing ratio measurement precision better than $0.5 \mathrm{~g} \mathrm{~kg}^{-1}$ in the $0-5-\mathrm{km}$ distance range from the aircraft. Because of the saturation of the lidar signal caused by high water vapor content in the $\mathrm{CBL}$ and the geometric factor of the lidar system as discussed in Murphey et al. (2006) the usable lidar water vapor measurements only exist between 1.2 and $3.5-4 \mathrm{~km}$ along the lidar line of sight. 
A two-pass Barnes (1973) filter was used to interpolate the lidar water vapor field onto the same Cartesian grid used for ELDORA wind syntheses. The cutoff radius, the smoothing parameter, and the convergence parameter were set to $600 \mathrm{~m}, 600 \mathrm{~m}^{2}$, and 0.3 , respectively. These parameters were chosen so that the resolution of the moisture field was comparable to the ELDORA dual-Doppler wind syntheses.

\section{Environmental conditions}

Subjective surface analyses superimposed on the visible satellite imagery at 2000, 2100, 2200, and 2300 UTC (hereafter, all times are UTC) in the IHOP_2002 domain are shown in Fig. 1. Upper-level charts indicate no significant disturbances over the Oklahoma panhandle where the IHOP_2002 IOR was located. A welldefined stationary frontal zone can be seen across Kansas from southwest to northeast at 2000. Also apparent is the dryline extending from central Kansas into the Oklahoma panhandle. A tornadic storm (storm A) was initiated around 2100 along the stationary front near Russell, Kansas. The winds northwest of the stationary front are generally weak and from the north-northeast, while the relatively strong southerly winds are advecting warm moist air southeast of the stationary front. The stationary front initiated another small storm (storm B) around 2207, and storm C was started along a roll boundary detected by S-Pol as a fine line southeast of the retreating dryline around 2210. During the period of intensive data collection from 2100 to 2330, no storms were formed inside the IHOP_2002 IOR in the Oklahoma panhandle, even though middle-level clouds with radar reflectivity greater than $18 \mathrm{~dB} Z_{\mathrm{e}}$ and boundary layer clouds were observed by ELDORA and IHOP_2002 personnel in the field (F. Fabry 2004, personal communication), respectively. One trend noticed from the surface data is the gradual drying of the surface layer throughout the region, with enhanced drying on the northwest side of the dryline. This gradual drying trend may be one of the many reasons that the dryline was prevented from initiating storms in this particular case.

The subjective surface analyses presented in Fig. 1 can be justified by the subjective surface potential temperature $(\theta)$ and equivalent potential temperature $\left(\theta_{\mathrm{e}}\right)$ analyses in Fig. 2. The stationary front across southcentral Kansas and the Oklahoma panhandle was characterized by a wind shift line. The dryline over the Oklahoma panhandle, which is the main focus of this study, was formed as a result of high $\theta_{\mathrm{e}}$ air pushing northwestward toward the stationary front in the warm sector (Fig. 2b). Both $\theta$ and $\theta_{\mathrm{e}}$ differentials were asso- ciated with this dryline, although they were relatively weak. Another dryline, which is a more traditional dryline in the sense that it separates the hot dry air on the west from the cooler moist air on the east, can be identified over the Texas panhandle. As the high $\theta_{\mathrm{e}}$ air pushed farther northwestward, these two drylines seem to become connected (Fig. 2d). It should be noted that the dryline over the Oklahoma panhandle was not identifiable if the IHOP_2002 special datasets were not available (surface analyses from NCEP did not show this dryline).

The movement of the dryline within the Oklahoma panhandle during the data collection period from 2000 to 2330 is shown in Fig. 3. The dryline position was obtained from S-Pol radar reflectivity fine lines. It is estimated that the dryline was moving at $\sim 2.5 \mathrm{~m} \mathrm{~s}^{-1}$ from $138^{\circ}$ until 2200 when its speed slowed down to $\sim 1.5 \mathrm{~m} \mathrm{~s}^{-1}$. The retreating dryline has been studied in a number of cases, and the mechanism of its propagation has been debated among different investigators. One hypothesis is the density current analogy. Parsons et al. (1991), among others, demonstrated that the dryline was retreating to the west at a speed close to the expected density current speed. On the other hand, Crawford and Bluestein (1997) showed surface observations that suggest that the passage of a dryline does not resemble that of a typical density current, such as a gust front. This issue will be addressed in section 5 with NCAR mobile soundings and Learjet dropsonde data.

\section{S-Pol radar reflectivity and refractivity}

The S-Pol radar reflectivity and refractivity fields associated with the 11 June 2002 dryline are shown in Fig. 4. The dryline is delineated by a radar reflectivity fine line that is oriented southwest-northeast. Generally the greatest gradient of radar refractivity is closely associated with or slightly northwest of the radar reflectivity fine line. Larger refractivity values that correspond to greater moisture can generally be seen southeast of the retreating dryline. Noteworthy is the variability of moisture in the along-line direction as demonstrated in the radar refractivity fields northwest of the dryline. The NRL P-3 aircraft tracks are also plotted in Fig. 4. The radar refractivity along the track is compared with the mixing ratio at the flight level (600 m AGL) in Fig. 5. General agreement between the trend of mixing ratio and radar refractivity ( $\mathrm{N}$ value) are found for the three legs shown in Fig. 4, although much more detailed variations can only be seen in the flight-level data. This is not surprising since the radar refractivity has a lower effective resolution $(\sim 4 \mathrm{~km})$ compared with that of flight-level data $(\sim 110 \mathrm{~m})$. Although the S-Pol radar 

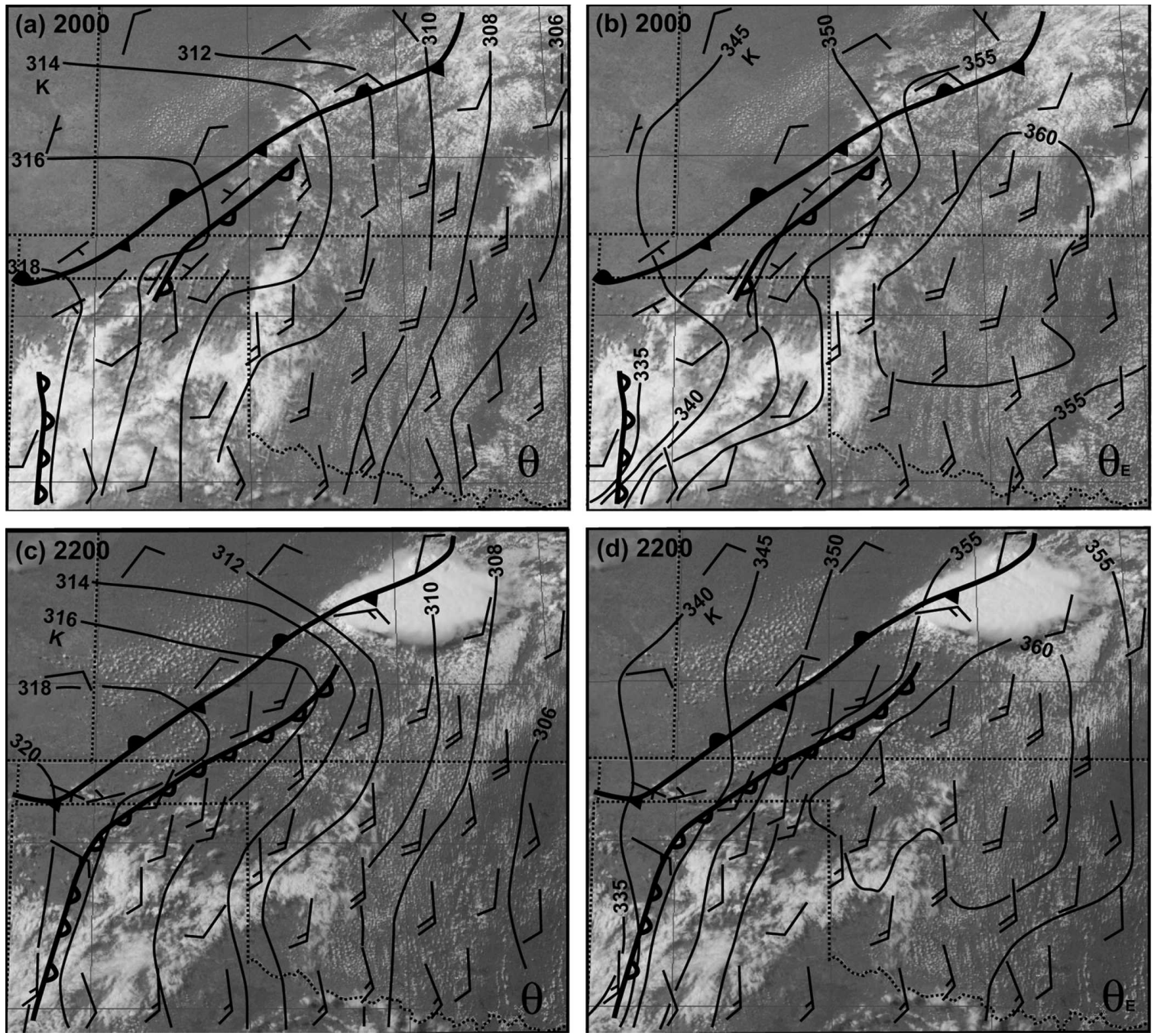

FIG. 2. Potential temperature $(\theta)$ and equivalent potential temperature $\left(\theta_{\mathrm{e}}\right)$ analyses superimposed on the visible satellite images at 2000 and 2200 UTC on 11 Jun 2002: (a) $\theta$ at 2000 UTC, (b) $\theta_{\mathrm{e}}$ at $2000 \mathrm{UTC}$, (c) $\theta$ at $2200 \mathrm{UTC}$, and (d) $\theta_{\mathrm{e}}$ at 2200 UTC. Wind vectors are plotted with full barb and half barb representing 5 and $2.5 \mathrm{~m} \mathrm{~s}^{-1}$, respectively.

refractivity data have the same nominal resolution as radar reflectivity $(\sim 150 \mathrm{~m}$ gate length), its effective resolution is much lower as a result of filtering and smoothing by the algorithm used to derive radar refractivity. Other reasons that might contribute to the discrepancy of mixing ratio and $\mathrm{N}$ values are believed to be 1) the height difference between flight-level data ( $\sim 600 \mathrm{~m} \mathrm{AGL})$ and refractivity data (near the surface) and 2) pressure and temperature effects on the radar refractivity in addition to moisture. For a detailed intercomparison between S-Pol radar refractivity and other moisture measurements, the reader is referred to Weckwerth et al. (2005).

Another pronounced feature in Fig. 4 is the roll boundary that was associated with a radar reflectivity fine line southeast of the dryline. This roll boundary probably originated from a well-defined HCR and was associated with much larger radar reflectivity values. Since stronger radar reflectivity of a fine line usually implies stronger convergence and updrafts (Wilson et al. 1994; Hane et al. 2002), the best chance for convection initiation might well be associated with this roll boundary. In fact there was a storm (storm C in Figs. 1 and 13) that was initiated along this roll boundary around 2210.

\section{ELDORA, LEANDRE II, and NRL P-3 flight-level data analysis}

\section{a. Along-line variability}

The dual-Doppler synthesis from ELDORA for the 11 June 2002 dryline is shown in Fig. 6. Also plotted in 


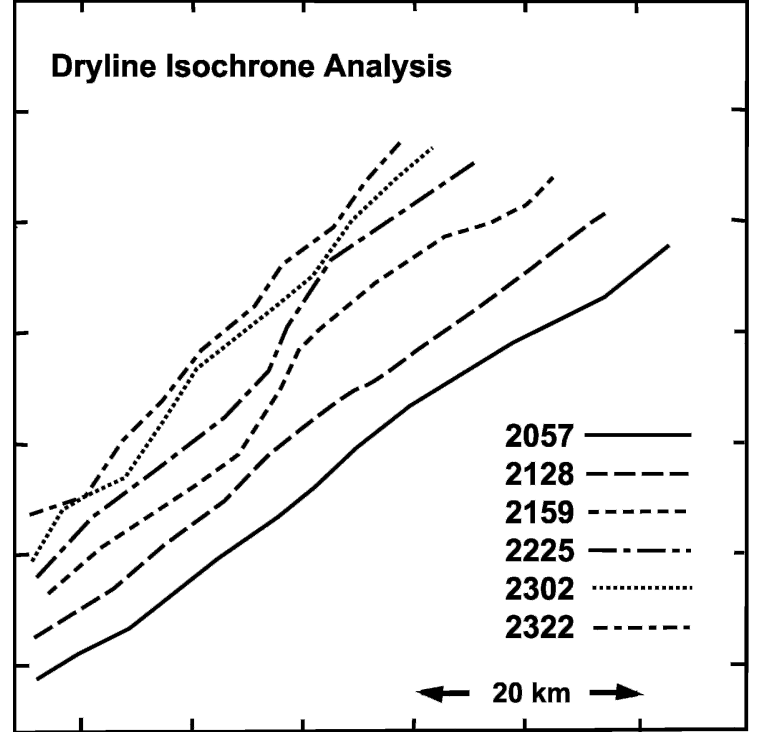

FIG. 3. Isochrone analysis of the dryline position within the IHOP_2002 IOR in the Oklahoma panhandle derived from S-Pol radar reflectivity for times (UTC) shown in the figure.

the right panels of Fig. 6 are the echoes from the middle-level clouds near the dryline observed by ELDORA. In the high-resolution ELDORA observations of radar reflectivity, the dryline is shown with significant along-line variability that has been documented in previous studies (Atkins et al. 1998). The dryline was fairly linear in the radar reflectivity field at 2108-2116 (Fig. 6a). By 2214-2228, it developed a kink near the middle of the domain (Fig. 6c). As a result of that, the NRL P-3 actually flew within the dryline starting around 2221:30 when the flight-level mixing ratio showed strong variability (Fig. 5b). The mixing ratio at flight level shows a sharp drop from 13 to $9 \mathrm{~g} \mathrm{~kg}^{-1}$ at 2223:30 as the P-3 completely penetrated the kink in the dryline. The moisture recovered shortly after 2225 when the P-3 was southeast of the dryline again (see Figs. $5 b$ and $6 c$ ).

The strong variability of the moisture field along the dryline during 2218-2227 was also nicely captured by LEANDRE II. Figure 7 shows the water vapor mixing ratio obtained by the lidar superimposed on drylinerelative winds, radar reflectivity, and vertical velocity within the box shown in Fig. 6c. Clearly the dryline demonstrated considerable along-line variability both in terms of radar reflectivity and water vapor mixing ratio. The dryline-relative winds have a larger cross-line component northwest of the dryline kink region within the dry air, confirming that the dryline kink was a pocket of dry air pushing eastward. As shown by the S-Pol radar reflectivity and refractivity data in Fig. 4, Fig. 7 confirms that the radar reflectivity fine line is closely associated with the greatest moisture gradient of the dryline. A careful examination of the relation between local maxima of radar reflectivity, water vapor mixing ratio, and vertical velocity suggests that generally the radar reflectivity maxima are closely associated with pockets of high moisture content air and updrafts with a few exceptions at the northeast corner of Fig. 7. There is also strong indication that stronger reflectivity values tend to correspond to stronger updrafts, which is consistent with previous findings (Wilson et al. 1994; Hane et al. 2002).

The dryline became quasi-linear again during 2310 2321 and the general trend of weakening radar reflectivity continued (Figs. 6e,f). The flight-level mixing ratio confirms that the P-3 is on the dry side of the moisture gradient except at the very beginning of the flight leg where large variations of moisture were observed (Fig. 5c). The reason for this is because although generally the aircraft was flying on the dry side, it was near the reflectivity maxima at the beginning of the track (Fig. 6e). Remember the reflectivity fine line is a good indicator of a larger moisture concentration; therefore when the P-3 was getting closer to those reflectivity maxima, the moisture increased dramatically.

\section{b. Cross-line variability}

The cross-line variability of water vapor mixing ratio and $\theta_{\mathrm{v}}$ derived from NRL P-3 flight-level data is shown in Fig. 8. The time series of water vapor mixing ratio and $\theta_{\mathrm{v}}$ for three short legs perpendicular to the dryline near the southwest corner of IHOP_2002 IOR are shown. The mixing ratio decreased by $\sim 4 \mathrm{~g} \mathrm{~kg}^{-1}$ across the dryline zone of 4.4-6.6 km (the dryline zone width was determined by cross-line flight-level data). Although the moisture differential did not change much from 2118 to 2306, the boundary layer moisture decreased by $\sim 3 \mathrm{~g} \mathrm{~kg}^{-1}$ on both sides of the dryline during this same time period. The reason for this is because the south-southwesterly winds near the dryline were advecting dry air from the northern Texas panhandle to the Oklahoma panhandle, causing the general drying trend in the CBL over the IHOP_2002 IOR (see surface analysis in Figs. 1 and 13). The $\theta_{\mathrm{v}}$ differential across the dryline is $\sim 0.5 \mathrm{~K}$, but it is not necessarily collocated with the mixing ratio differential. The winds near the dryline were generally weak $\left(2.5-7.5 \mathrm{~m} \mathrm{~s}^{-1}\right)$ and had a larger westerly component northwest of the dryline, whereas southeast of the dryline winds were mostly from south-southwest.

The averaged vertical cross sections perpendicular to the dryline are shown in Figs. 9-11. These cross section were obtained by averaging over $\sim 8,10$, and 9 min data (which correspond to 52,66 , and $60 \mathrm{~km}$ in the along-line 
(a) 2113:07 - 2118:05

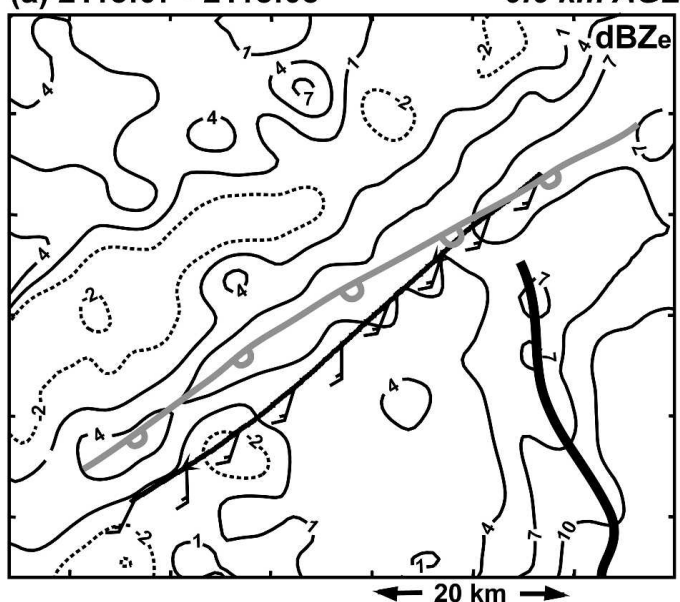

(c) 2220:39 - 2225:35

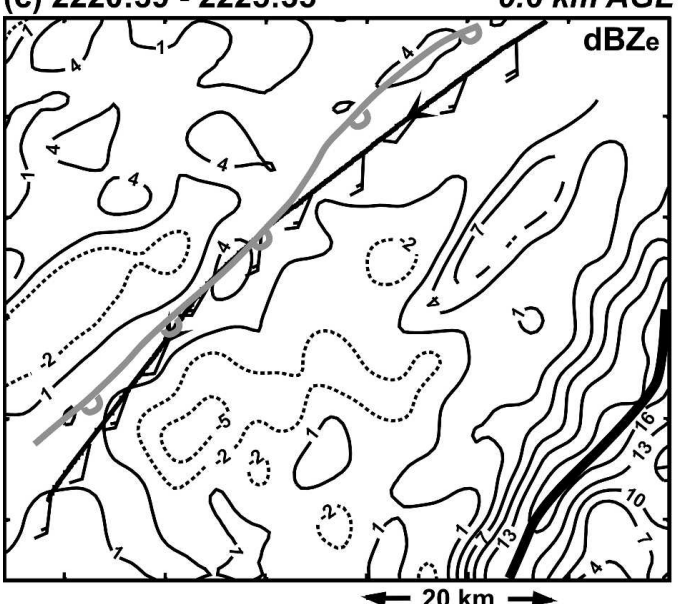

(e) 2317:43 - 2322:35

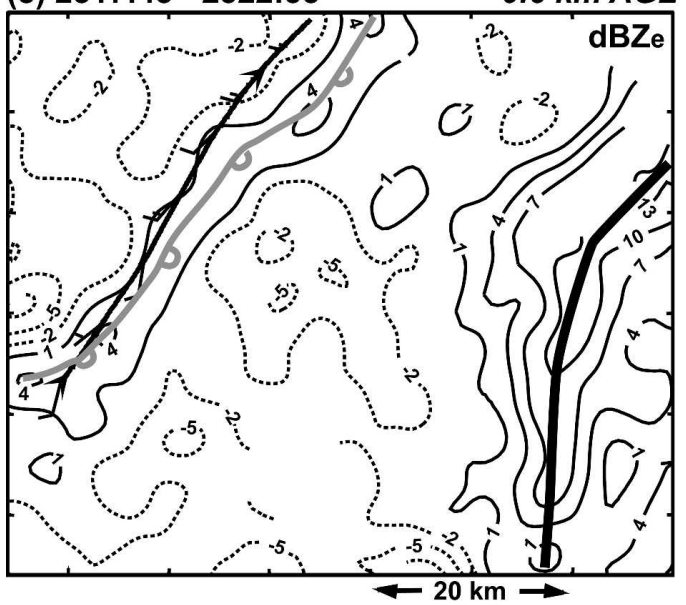

(b) 2113:03 - 2113:35

$0 \mathrm{~km} A G L$
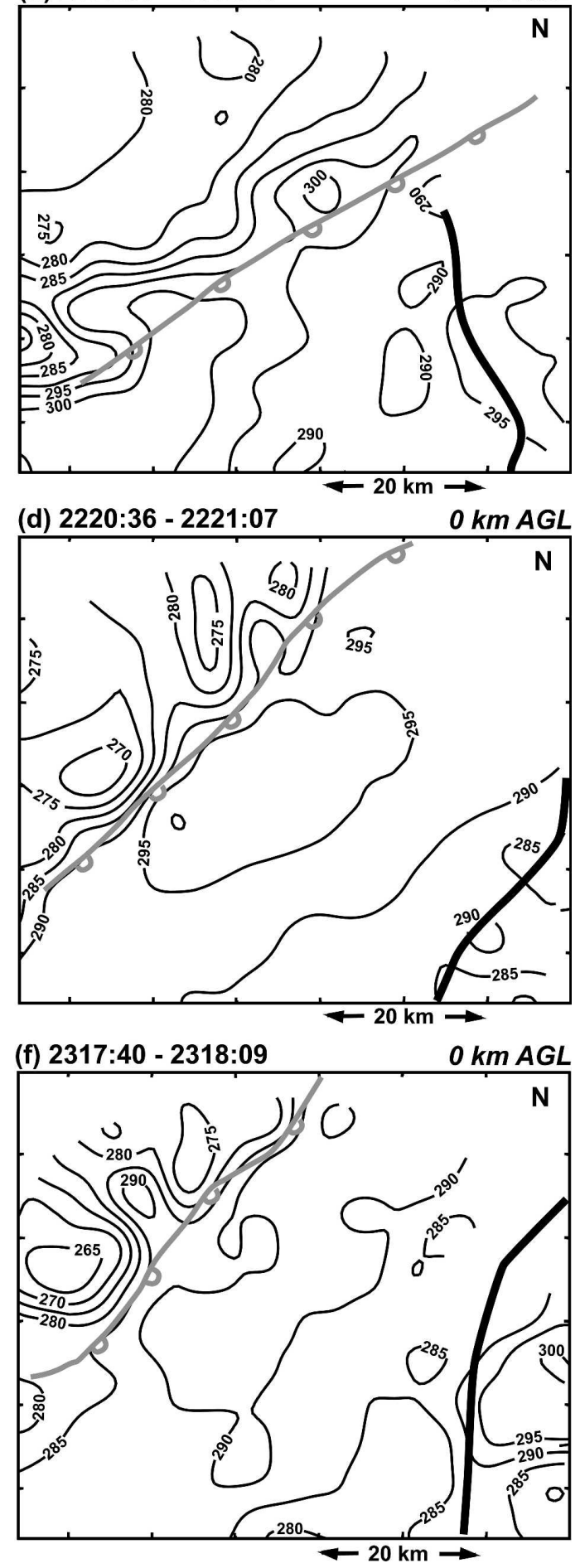

FIG. 4. S-Pol radar reflectivity at $0.6 \mathrm{~km}$ AGL and radar refractivity at surface. (a) Radar reflectivity at 2113:072118:05 UTC, (b) radar refractivity at 2113:03-2113:35 UTC, (c) radar reflectivity at 2220:39-2225:35 UTC, (d) radar refractivity at 2220:36-2221:07 UTC, (e) radar reflectivity at 2317:43-2322:35 UTC, and (f) radar refractivity at 2317:40-2318:09 UTC. The NRL P-3 flight track along with flight-level winds (black line) are also superimposed on (a), (c), and (e). The dryline fine line (gray line) derived from (a), (c), and (e) are also plotted in (b), (d), and (f), respectively. The thick black lines in all panels represent the roll boundary. The short time period for radar refractivity measurements in (b), (d), and (f) is because refractivity measurements were only made at $0^{\circ}$ elevation angle. 
(a) NRL-P3 Flight Level Data (2108 - 2116)
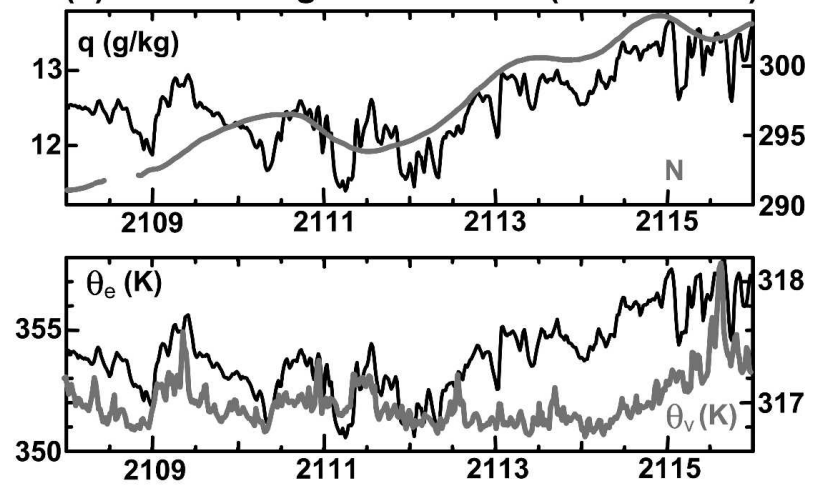

(b) NRL-P3 Flight Level Data (2214 - 2228)

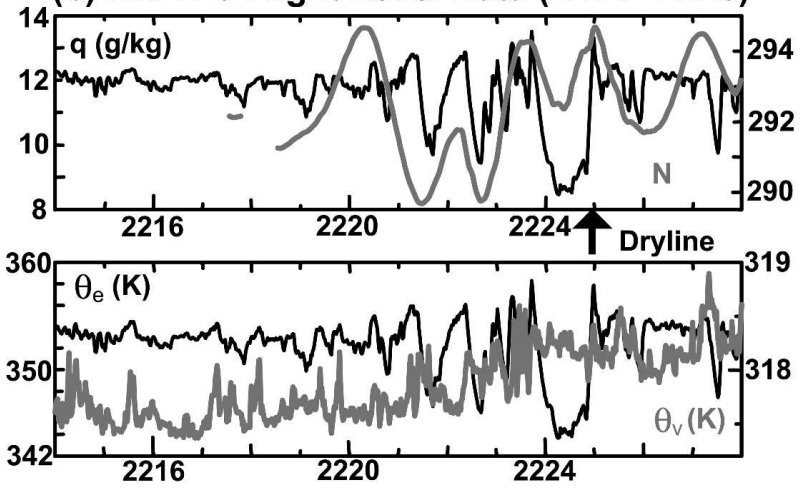

(c) NRL-P3 Flight Level Data (2310 - 2323)
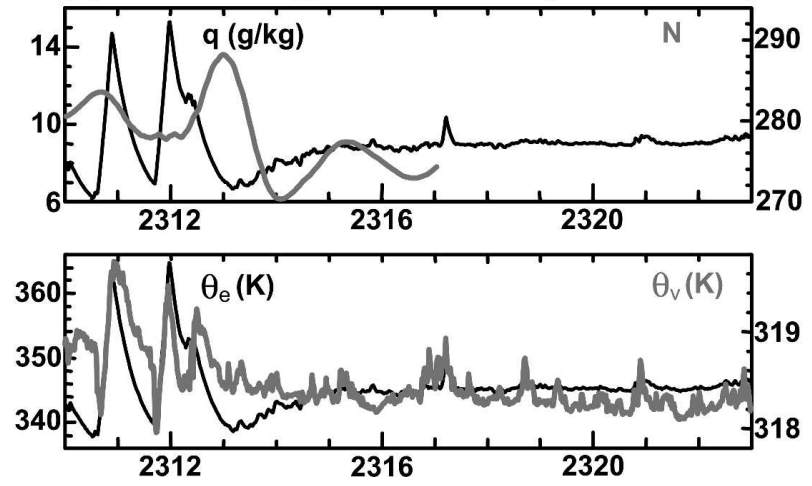

FIG. 5. Time series of NRL P-3 flight-level data as it flew at $\sim 600 \mathrm{~m}$ AGL along the dryline (see Figs. 4 and 6 for flight tracks). Water vapor mixing ratio $(\mathrm{q})$, virtual potential temperature $\left(\theta_{\mathrm{v}}\right)$, and equivalent potential temperature $\left(\theta_{\mathrm{e}}\right)$ are plotted. The S-Pol radar refractivity $(\mathrm{N})$ along the flight track is also plotted. (a) 2108-2116, (b) 2214-2228, and (c) 2310-2323 UTC.

direction, respectively) for the 2108-2116, 2214-2228, and 2310-2321 analysis times, respectively. The averaged cross section increased the signal-to-noise ratio by removing random noise and preserving the mean structure in the signal. Several features stand out in the averaged vertical cross sections of radar reflectivity, updraft, and vertical vorticity. Generally the strongest updraft is collocated or slightly northwest of the reflectivity fine line. Also there are very weak downdrafts $\sim 3-5 \mathrm{~km}$ southeast of the dryline (the retreating dryline was moving from southeast to northwest, that is, from right to left in Figs. 9-11). The wavelike pattern of updraft/downdraft associated with the dryline has been documented before (Parsons et al. 1991; Ziegler and Hane 1993). Another observation that stands out is the dissipating reflectivity fine line and the decreasing dryline updrafts with time.

Previous studies have shown that drylines behave like density currents (Parsons et al. 1991; Ziegler and Hane 1993; Atkins et al. 1998). However, Crawford and Bluestein (1997) demonstrated that some drylines do not look like a density current by studying dryline passage using surface mesonet data. Moreover, there are still uncertainties about whether there is a virtual potential temperature differential across the dryline. Early observations (NSSP Staff 1963) showed basically no $\theta_{\mathrm{v}}$ differential across the dryline, while more recent studies (Parsons et al. 1991; Ziegler and Hane 1993; Atkins et al. 1998) found $\theta_{\mathrm{v}}$ differential of $1-2 \mathrm{~K}$ across the dryline. The reconciliation of these contradicting observational results seems to come from what time during the dryline diurnal cycle the observations were made (Ziegler and Hane 1993). It is possible that when the dryline started to retreat back to the west during late afternoon hours, the $\theta_{\mathrm{v}}$ differential became more pronounced and the dryline started to behave like a density current.

The 11 June 2002 dryline studied in this paper shows some interesting features that have not been noted in a retreating dryline before. The $\theta_{\mathrm{v}}$ differential derived from NRL P-3 flight-level data (Figs. 5 and 8 ) is relatively weak $(\sim 0.5 \mathrm{~K})$. The weak baroclinity may contribute to the relatively weak updrafts near the dryline. It can be inferred that the dry air on the left side of Figs. 9 and 10 is lifted over the dryline and then sinks $2-5 \mathrm{~km}$ downstream as previous studies have shown before. However, there is no indication of a rotation head or secondary circulation, which are common in a typical density current. Also, using the density current formula with an assumption of an internal Froude number of one, the dryline motion based on Learjet dropsonde data is found to be $\sim 5.2 \mathrm{~m} \mathrm{~s}^{-1}$, which is much larger than the dryline motion of $2.5 \mathrm{~m} \mathrm{~s}^{-1}$ estimated from S-Pol reflectivity at this time. Therefore, it seems that the current dryline case does not fit a density current very well.

The dryline seems to be weakening during the observational period from 2100 to 2330 . The radar reflectivity, the updraft, and vertical vorticity all decreased significantly. The boundary layer is also drying out (see 
(a) 2108:03 - 2116:01

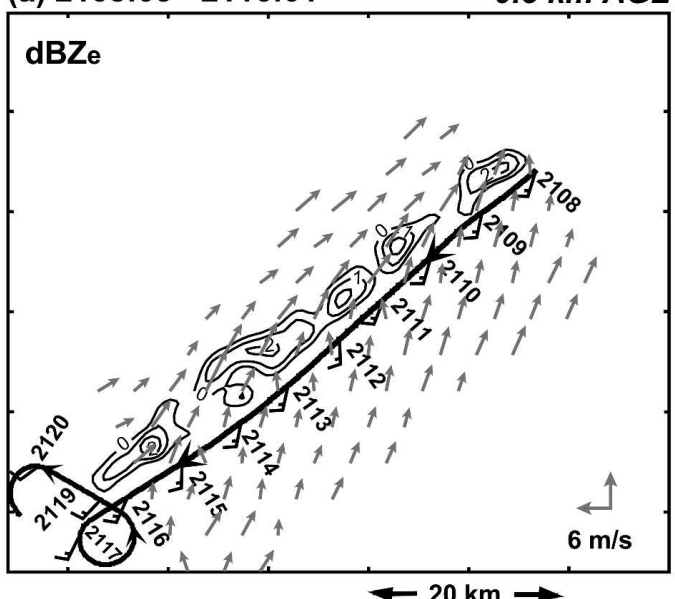

(c) 2214:02 - 2228:04

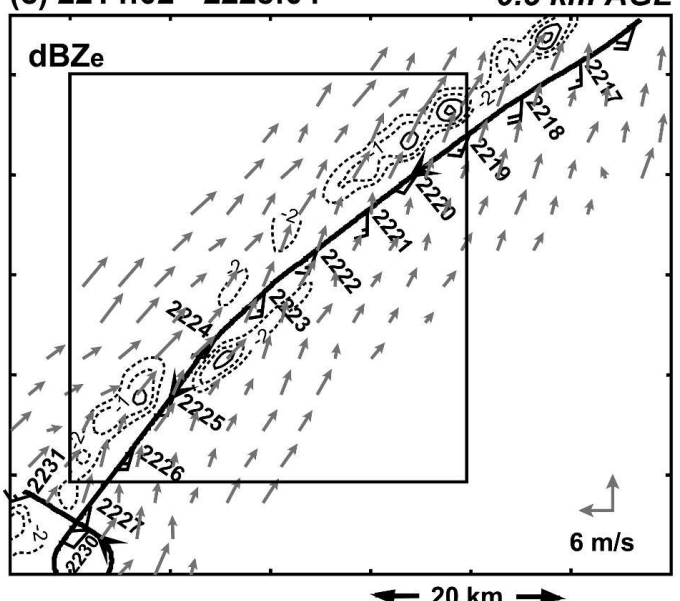

$0.5 \mathrm{~km} A G L$

(e) 2310:03 - 2321:33

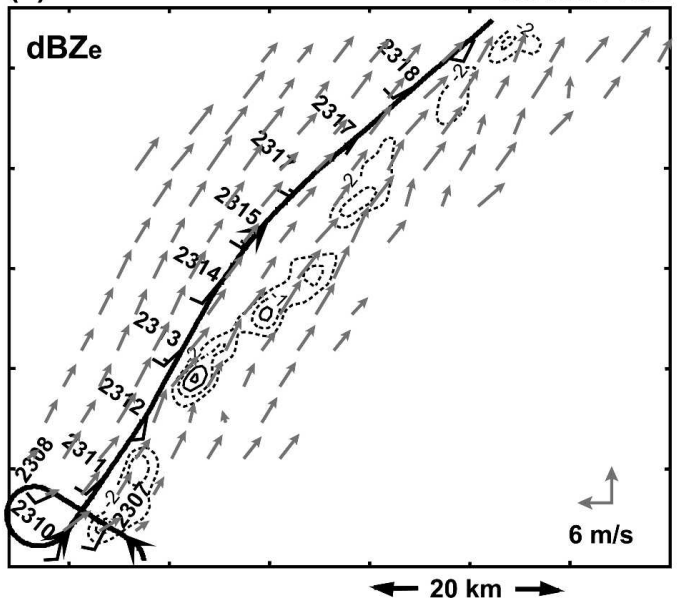

(b) 2108:03 - 2116:01

$5.3 \mathrm{~km}$ AGL
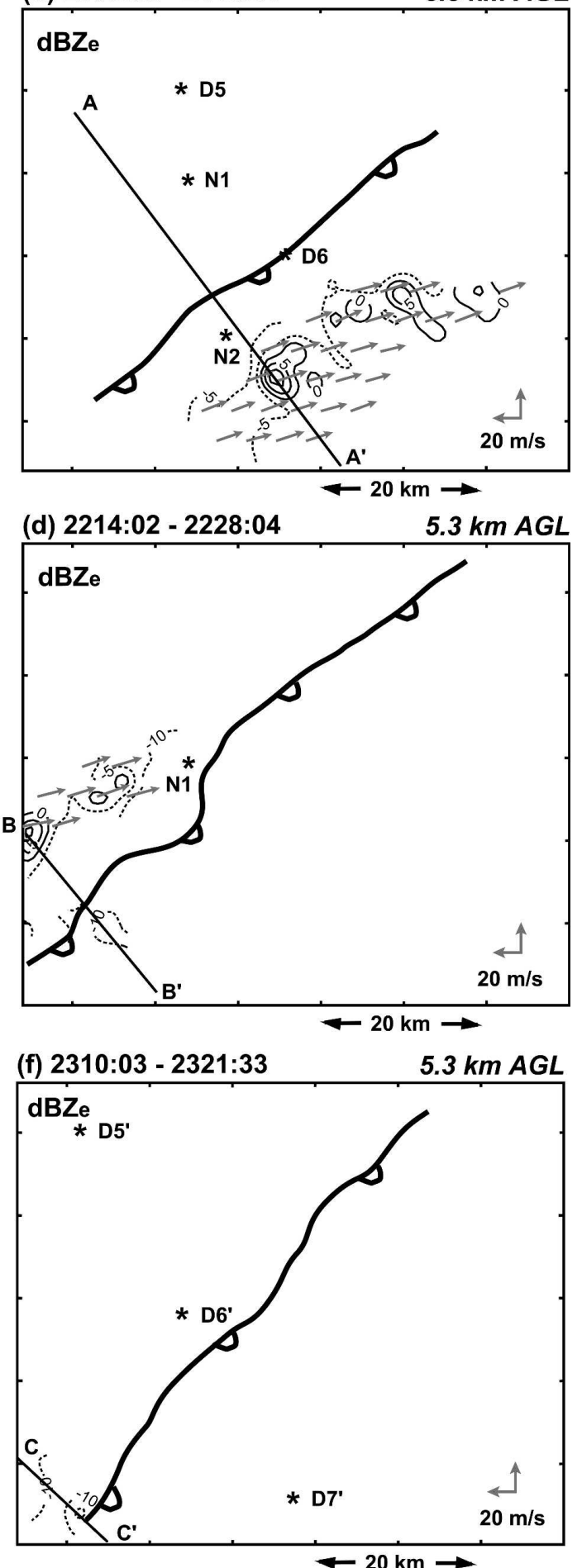

FIG. 6. Dual-Doppler wind synthesis (ground relative) and radar reflectivity from ELDORA at 0.5 and $5.3 \mathrm{~km}$ AGL near the dryline; (a) 2108:03-2116:01 UTC at 0.5 km AGL, (b) 2108:03-2116:01 UTC at 5.3 km AGL, (c) 2214:02-2228:04 UTC at 0.5 km AGL, (d) 2214:02-2228:04 UTC at 5.3 km AGL, (e) 2310:03-2321:33 UTC at 0.5 km AGL, and (f) 2310:03-2321:33 UTC at $5.3 \mathrm{~km}$ AGL. Thin black contours represent radar reflectivity with dashed lines indicating negative reflectivity values. Contour interval is $1 \mathrm{~dB} Z_{\mathrm{e}}$ in (a), (c), and (e) and $5 \mathrm{~dB} Z_{\mathrm{e}}$ in (b), (d), and (f). NRL P-3 flight tracks (black lines) along with time and flight-level winds are plotted in (a), (c), and (e). The dryline fine line positions derived from (a), (c), and (e) are plotted as thick black lines in (b), (d), and (f), respectively. N1 and N2 in (b) represent the positions of NCAR MGLASS soundings at 2137 and 2051 UTC, respectively. D5 and D6 in (b) indicate two Learjet dropsondes at 2146 and 2149 UTC, while D5', D6', and D7' in (f) represent three dropsondes at 2331, 2334, and $2337 \mathrm{UTC}$, respectively. A-A', B-B', and $\mathrm{C}-\mathrm{C}^{\prime}$ are the positions of individual vertical cross sections shown in Figs. 12a-c. The black box in Fig. 6c represents the domain used in Fig. 7. 


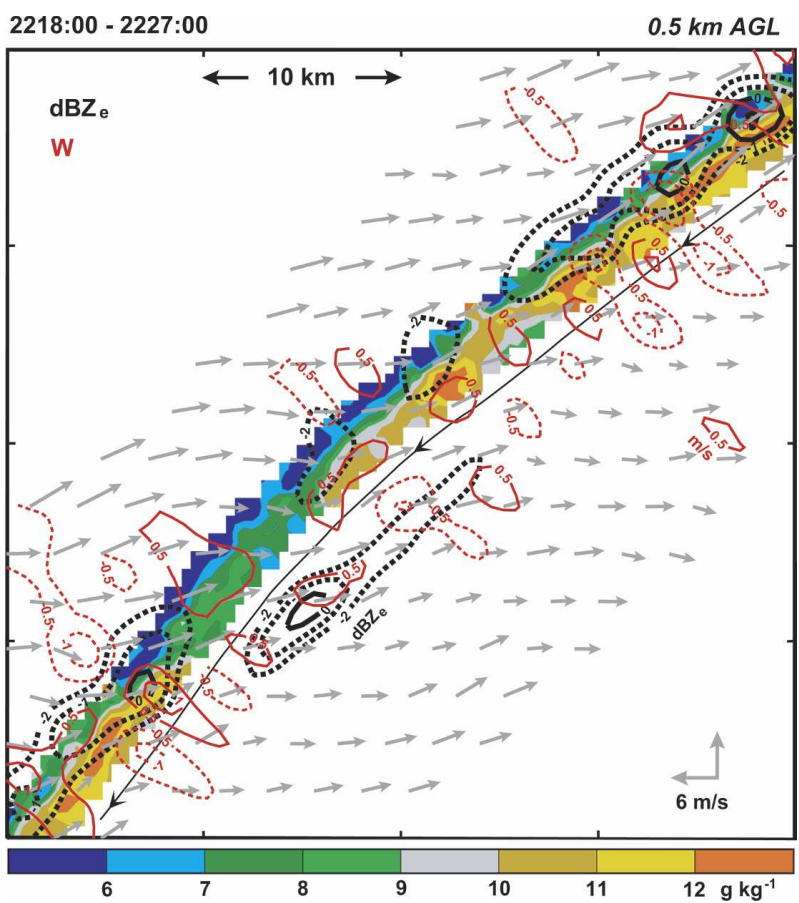

FIG. 7. Water vapor mixing ratio from LEANDRE II superimposed on dryline-relative winds, radar reflectivity, and vertical velocity from ELDORA at 0.5 km AGL for 2218:00-2227:00 UTC. Solid (dashed) red line represents updraft (downdraft) with contour interval of $0.5 \mathrm{~m} \mathrm{~s}^{-1}$; thick solid (dashed) black line represents positive (negative) radar reflectivity values with contour interval of $1 \mathrm{dBZ} Z_{\mathrm{e}}$. The NRL P-3 flight track is drawn as the thin black line.

Figs. 1 and 13) and clouds are dissipating inside the IHOP_2002 IOR.

\section{c. The cloud fields near the dryline}

The dryline was accompanied by middle-level clouds at 2108-2116 (Fig. 6b). Satellite imagery loops indicate that these middle-level clouds were advected into the IHOP_2002 IOR and they tended to dissipate after they entered the Oklahoma panhandle region. Clouds can be seen on both sides of the dryline and sometimes right over the dryline as shown in Fig. 6. Some of them have radar reflectivity values as large as $18 \mathrm{~dB} Z_{\mathrm{e}}$. Vertical cross sections of both dryline and clouds are shown in Fig. 12. The clouds are middle level based and the maximum reflectivity of these clouds is located around $5.5 \mathrm{~km}$ AGL. All clouds are found to be within $15 \mathrm{~km}$ of the dryline. The dryline itself is shown as a reflectivity maximum in all three analyses times and found to be associated with updrafts of $2-3 \mathrm{~m} \mathrm{~s}^{-1}$ (The cross sections in Fig. 12 are not necessarily cutting through the updraft maximum; therefore their updraft values are lower). By 2310-2321 the clouds almost disappeared (a) 2118:30 - 2120:00

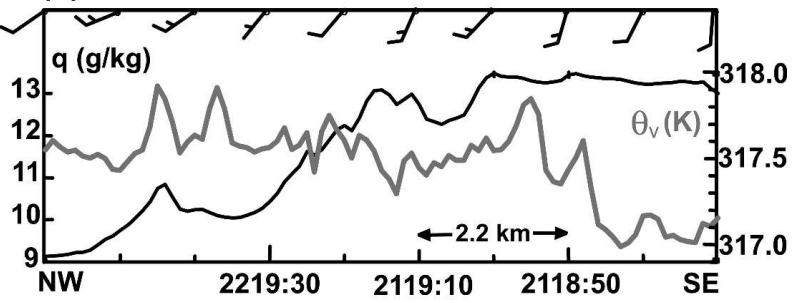

(b) 2229:40 - 2231:00

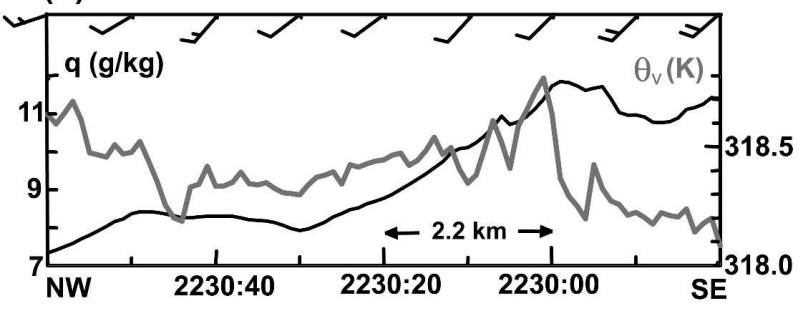

(c) $2306: 30$ - 2308:00

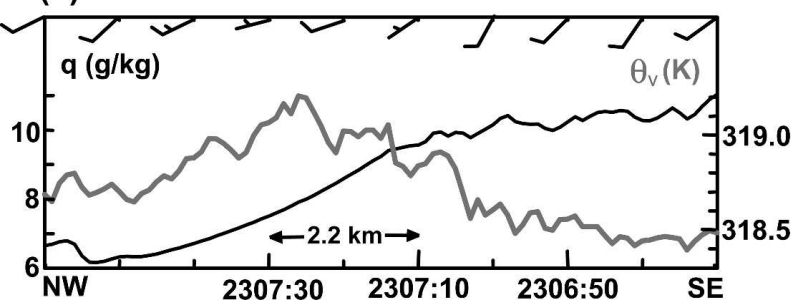

FIG. 8. Time series of NRL P-3 flight-level data as it flew at $\sim 600 \mathrm{~m}$ AGL across the dryline (see Fig. 6 for the flight tracks). Water vapor mixing ratio $(\mathrm{q})$, virtual potential temperature $\left(\theta_{\mathrm{v}}\right)$, and winds are plotted. (a) 2118:30-2120:00, (b) 2229:40-2231:00, and (c) 2306:30-2308:00 UTC.

except for a few low-reflectivity clouds just above the dryline. The reason for cloud dissipation will be discussed in section 7. It should be emphasized that the middle-level clouds in Figs. 6 and 12 were not connected to the dryline at all and they failed to develop into storms as they moved near the dryline, although previous studies have shown that sometimes middlelevel clouds did develop into storms when they approached drylines (Hane et at. 1997).

The dryline, roll boundary, and Learjet dropsonde positions superimposed on satellite imagery with surface analysis are shown in Fig. 13. The individual clouds in Figs. 12a-c are indicated in Figs. 13a-c as small circles. The dryline and roll boundary positions are obtained from S-Pol radar reflectivity. It is apparent that some clouds do not show up in radar observations even though they can be clearly identified on the satellite image. One example of this mismatch is the cloud line right above the surface dryline at 2112 in Fig. 13a. Those clouds were found to be connected to the boundary layer and probably were initiated by the dryline 
2108:03 - 2116:01
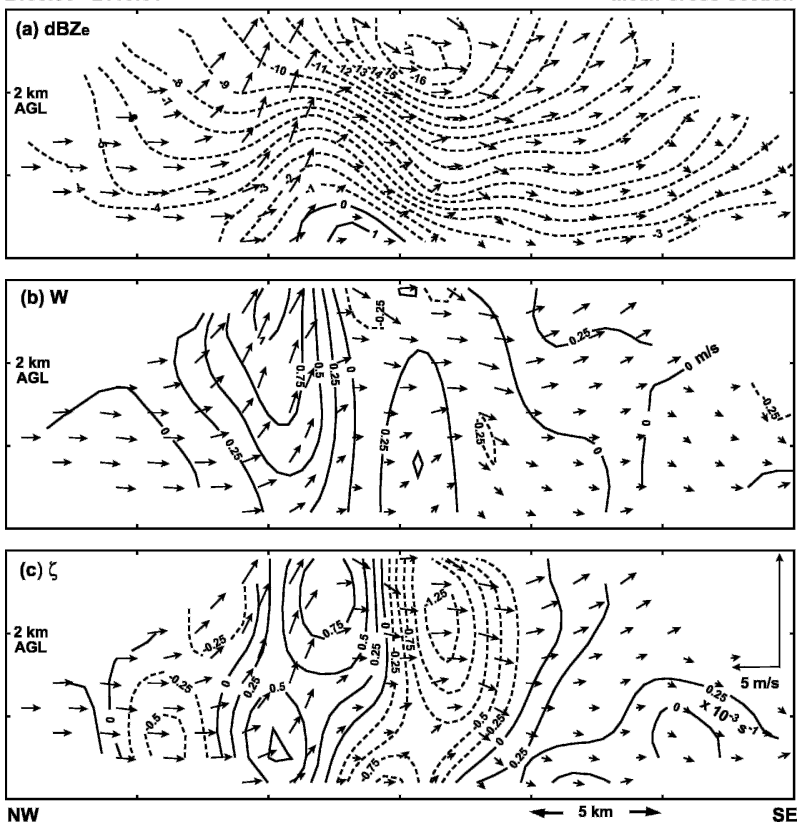

FIG. 9. Mean vertical cross section of the dryline for 2108:032116:01 UTC. Dual-Doppler winds (dryline relative) superimposed onto (a) radar reflectivity, (b) vertical velocity, and (c) vertical vorticity.

(Fabry 2006). Interestingly those clouds did not evolve into storms and they were not detected by ELDORA. The cloud line seen by ELDORA in Fig. 6b was $\sim 13$ $\mathrm{km}$ southeast of the surface dryline in the moist air
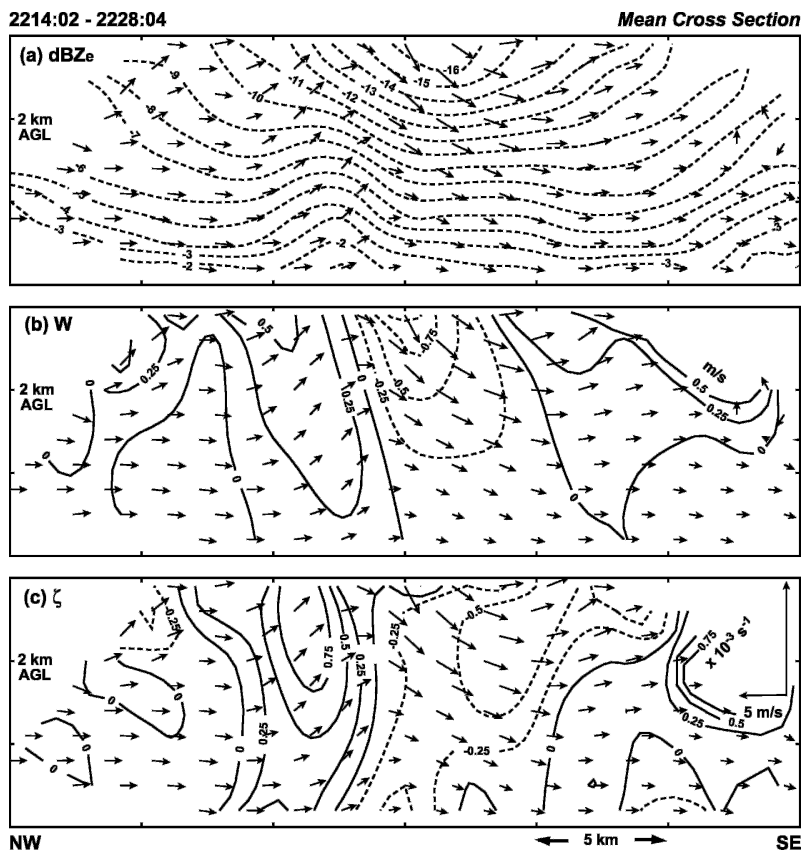

FIG. 10. Same as Fig. 9 except for 2214:02-2228:04 UTC.
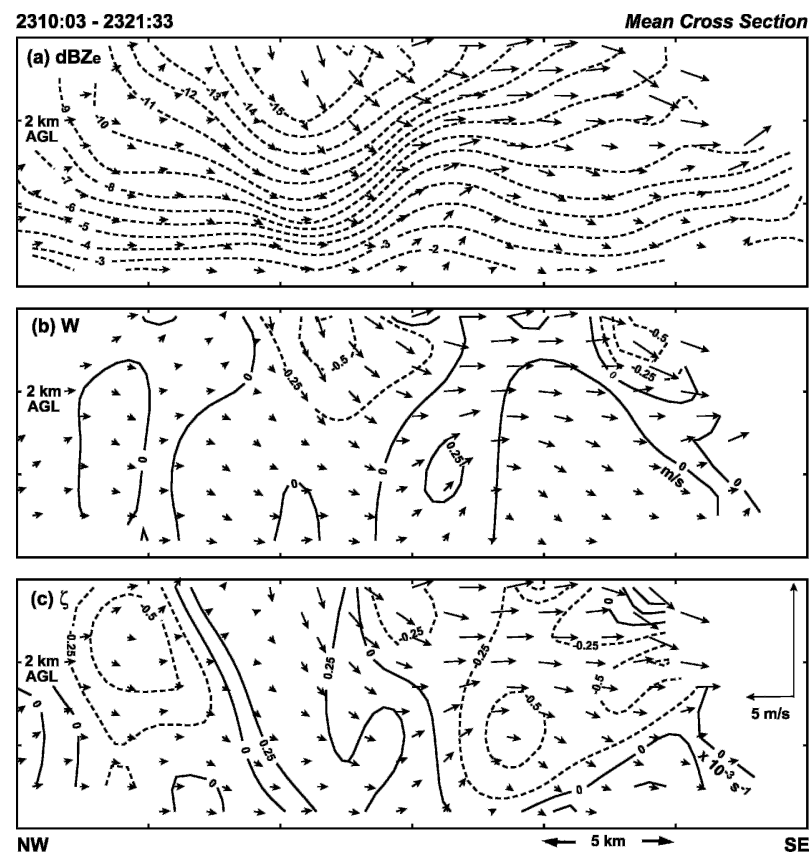

FIG. 11. Same as Fig. 9 except for 2310:03-2321:33 UTC.

mass and was middle level based. On the other hand, darker clouds, which might be difficult to identify in visible satellite imagery, are sometimes actually associated with much large radar reflectivity, such as the clouds at the west edge of analysis domain in Fig. $13 \mathrm{~b}$. By 2319 the clouds inside the IHOP_2002 IOR are almost all dissipated. Surface observations also show this general drying trend on both sides of the dryline. One interesting thing is that the roll boundary, which perhaps was associated with the best combination of convergence and moisture based on its much stronger reflectivity observed by S-Pol (Fig. 4) and larger surface moisture content shown in the surface analysis (Fig. 13), did initiate a storm (storm C in Figs. 1d, 13b, and 13c) at 2207. The first echo was identified at $4.7 \mathrm{~km}$ AGL in S-Pol reflectivity with a value of $23 \mathrm{dBZ}$. The echo grew both horizontally and vertically (upward and downward) and reached a maximum reflectivity value of $60 \mathrm{~dB} Z_{\mathrm{e}}$ by 2300 . After the initiation, storm C moved northeast away from the roll boundary and the storm dissipated around 0015 on 12 June 2002.

\section{Learjet dropsonde data analysis}

One advantage of IHOP_2002 compared to other field campaigns studying drylines is its deployment of dropsonde aircraft. Many previous dryline studies relied heavily on aircraft in situ measurements using the stepped-traverse flying pattern and the data usually 


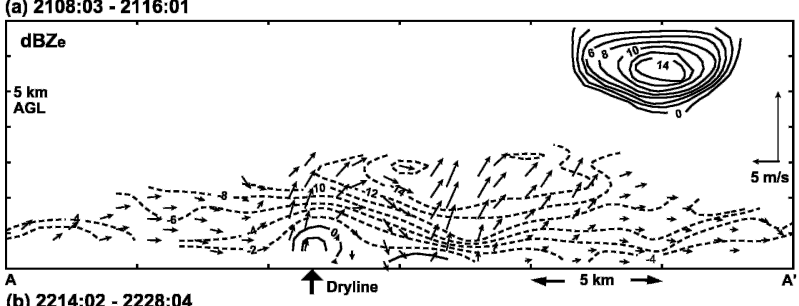

(b) 2214:02 - 2228:04
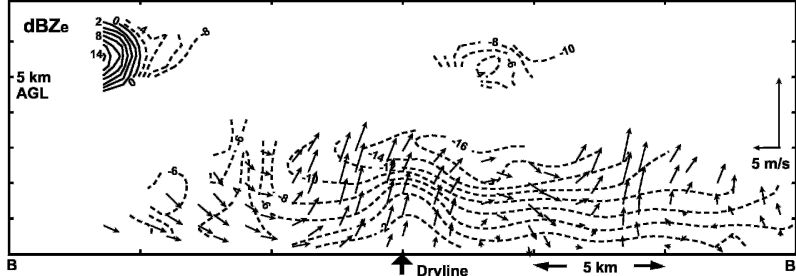

(c) 2310:03 - 2321:33

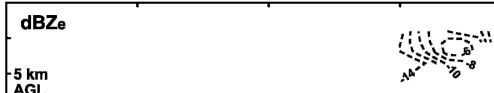

AG

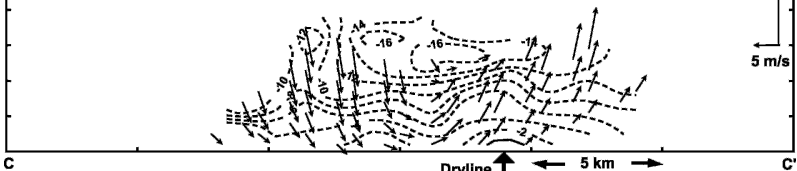

FIG. 12. Individual vertical cross section of dual-Doppler winds (dryline relative) and radar reflectivity from ELDORA at (a) 2108:03-2116:01, (b) 2214:02-2228:04, and (c) 2310:03-2321:33 UTC analysis times. The positions of the cross sections in (a), (b), and (c) are shown in Figs. 6b, 6d, and 6f, respectively.

have poor time and/or vertical resolution. The advantage of dropsonde aircraft is its ability to release soundings in rapid succession, and therefore the dropsonde data can cover a larger area in a relatively short time period with high spatial resolution. On 11 June 2002 a Learjet released two lines of dropsondes perpendicular to the dryline at 2134-2159 and 2322-2345 when ELDORA was collecting dual-Doppler data on the dryline. The position of each drop is plotted in Fig. 13 with respect to the dryline and roll boundary positions. The horizontal drift of the dropsondes was not cor-

FIG. 13. Surface analyses superimposed on visible satellite images at (a) 2112, (b) 2221, and (c) 2319 UTC. Temperature and dewpoint temperature are shown $\left({ }^{\circ} \mathrm{C}\right)$. Wind vectors are plotted with the full barb and half barb representing 5 and $2.5 \mathrm{~m} \mathrm{~s}^{-1}$, respectively. The box represents the dual-Doppler domain in Fig. 6. Thin black line represents the dryline; thick black line represents the roll boundary. Dropsonde positions are plotted as asterisks, and the black dot indicates the S-Pol radar position. D1-D9 in Figs. 13a and 13b represent the 2134-2159 UTC drop series, and D1'-D9' in Fig. 13c represent the 2322-2345 UTC drop series. The clouds shown in Fig. 12 are represented by small open circles. rected during IHOP_2002 and it should not cause any concern if the winds aloft were not so strong. Each drop is roughly separated by $20-25 \mathrm{~km}$ and each cross section contains nine drops that cover a distance of $\sim 200 \mathrm{~km}$ in
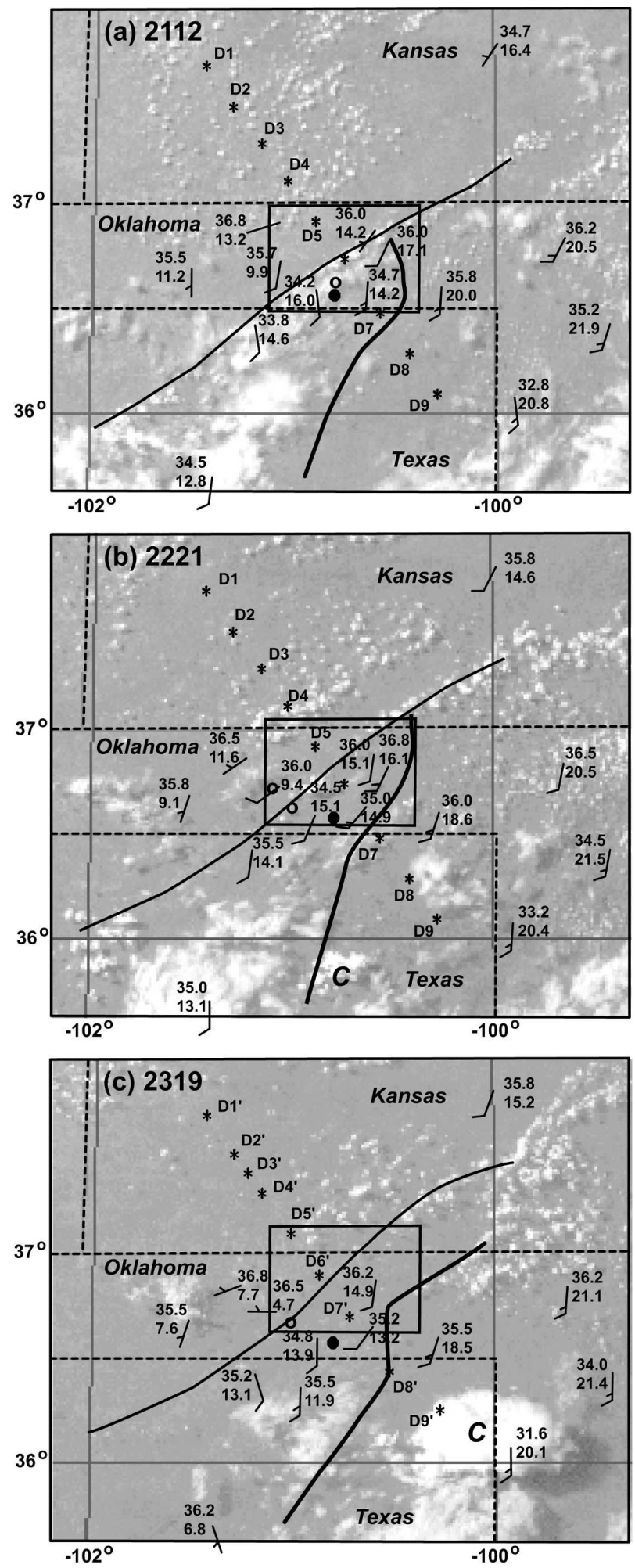
the cross-line direction. Basically the dropsonde data will provide information about the mesoscale environment, not the detailed structure of the dryline.

The water vapor mixing ratio shown in Fig. 14 indicates that the CBL is well mixed and the boundary layer top is higher within the dry air mass. The dry layer between 700 and $500 \mathrm{mb}$ is apparent on both sides of the dryline. One interesting feature in Fig. 14 is that the moist plume corresponding to the height of the $9 \mathrm{~g} \mathrm{~kg}^{-1}$ mixing ratio contour reached $\sim 3.2 \mathrm{~km} \mathrm{MSL}$ approximately $60 \mathrm{~km}$ northwest of the dryline, but it only reached $\sim 2.2 \mathrm{~km}$ MSL southeast of the dryline. It also should be pointed out that the boundary layer is relatively dry even on the moist side of the dryline for this particular case (relative humidity only reaches $\sim 40 \%$ near the surface at the dryline).

The instability parameters calculated from each dropsonde using NCAR System for User-editing and Display of Soundings (SUDS) software are shown in Fig. 15 for 2134-2159. The lowest $50-\mathrm{mb}$ mean measurements were used for the calculations of all the lifted parcel parameters. The convective available potential energy (CAPE) values derived from both the dropsonde data and NCAR MGLASS soundings were only integrated up to $\sim 450 \mathrm{mb}$, which causes the CAPE values to appear to be incorrectly small and can be misleading. Therefore, attentions should only be paid to the variations, not the absolute values of the CAPE derived from dropsonde data. Caution should also be

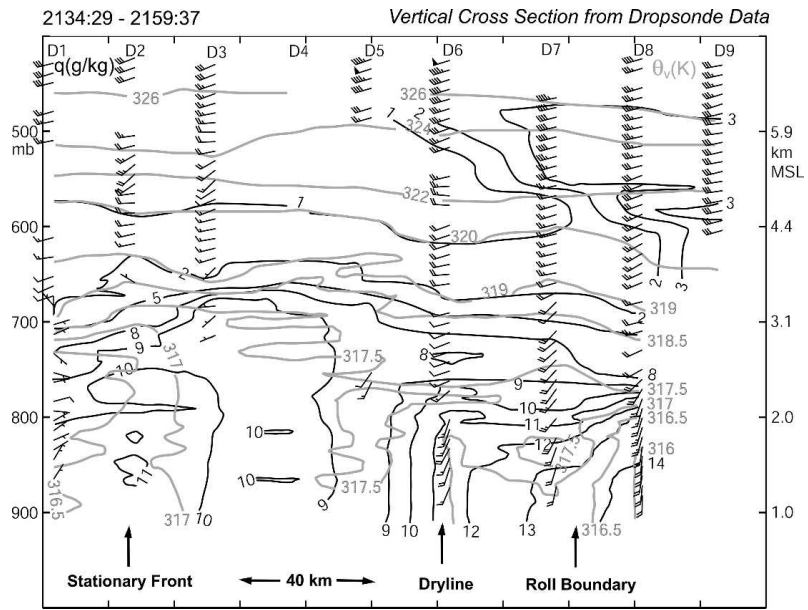

FIG. 14. Vertical cross section perpendicular to the dryline based on the dropsonde data between 2134:29 and 2159:37 UTC for water vapor mixing ratio $\left(q\right.$ in $\left.\mathrm{g} \mathrm{kg}^{-1}\right)$ and virtual potential temperature $\left(\theta_{\mathrm{v}}\right.$ in $\left.\mathrm{K}\right)$. The position of the stationary front, dryline, and the roll boundary are indicated at the bottom of the figure. Wind vectors are plotted with the half barb, full barb, and flag representing 2.5, 5.0, and $25 \mathrm{~m} \mathrm{~s}^{-1}$, respectively. D1-D9 represents each individual dropsonde, and their positions are plotted in Fig. 13a.

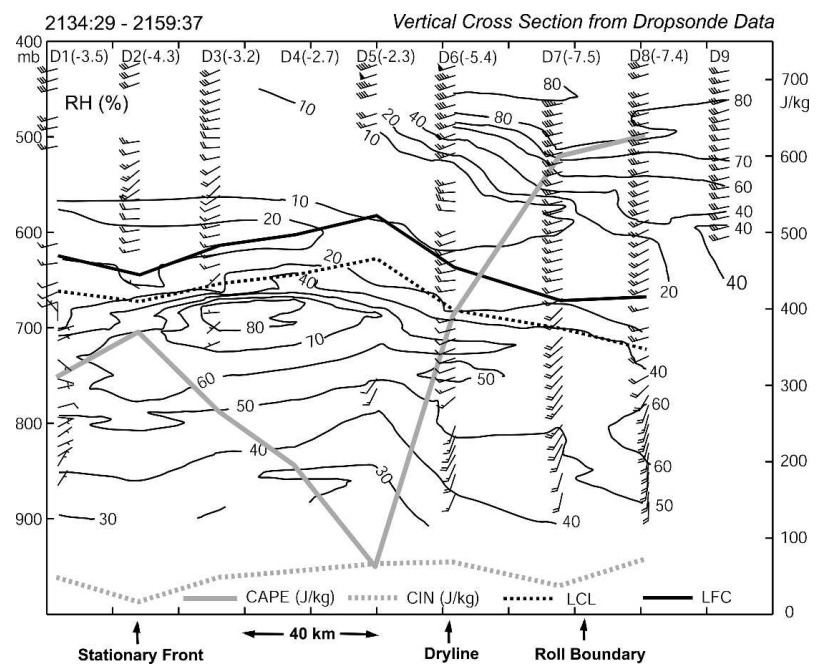

FIG. 15. Same as Fig. 14 except for relative humidity and instability parameters including CAPE, CIN, LI, LCL, and LFC; LI is labeled beside each dropsonde symbol (D1-D9) at the top of the figure.

exercised in interpreting the instability parameters calculated from the dropsondes since there is no way to know where those drops landed with respect to the boundary layer updrafts/downdrafts. As Fig. 15 shows, the CAPE reached a local maximum near the stationary front at first, then decreased to a minimum $\sim 20 \mathrm{~km}$ northwest of the dryline, and increased dramatically across the dryline and continued rising southeast of it. Convective inhibition (CIN), however, reached its minimum near the stationary front and its maximum $\sim 20 \mathrm{~km}$ northwest of the dryline. Generally the CIN values are between -30 and $-100 \mathrm{~J} \mathrm{~kg}^{-1}$, values that are too large for CI. Similar to CAPE, lifted index (LI) indicated very unstable air near the roll boundary. Both LCL and LFC reached their maximum $\sim 20 \mathrm{~km}$ northwest of the dryline and then decreased gradually southeastward. Notice it is the roll boundary, not the dryline, which is associated with larger CAPE, smaller LI, and lower CIN values. The stationary front is also a favorable place for CI since it is associated with the lowest CIN values.

The Learjet made the second line of drops at almost the same location as the first one about $2 \mathrm{~h}$ later. Figures 16 and 17 are the vertical cross sections obtained from the dropsonde data for 2322-2345. Two significant changes occurred between the two dropsonde vertical cross sections. One is the disappearance of the moist plume $\sim 60 \mathrm{~km}$ northwest of the dryline, and another is the increase in CBL depth southeast of the dryline. This is apparent through the $9 \mathrm{~g} \mathrm{~kg}^{-1}$ mixing ratio contour line, which used to be at the height of $\sim 2.2 \mathrm{~km}$ MSL and now reaches $3 \mathrm{~km}$ MSL southeast of the dryline. 


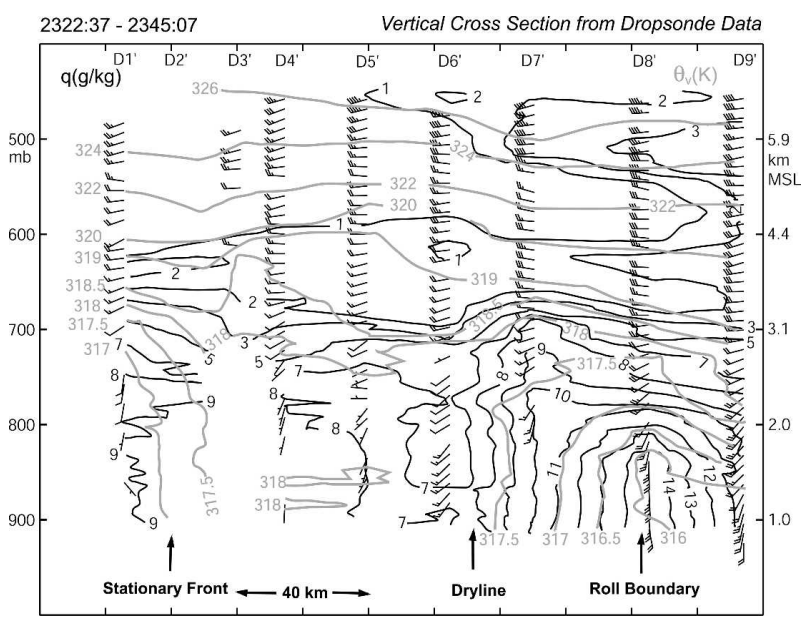

FIG. 16. Same as Fig 14 except for dropsonde data between 2322:37 and 2345:07 UTC. D1'-D9' represent each individual dropsonde, and their positions are plotted in Fig. 13c.

Again the similar pattern of instability parameters found in the previous cross section (Fig. 15) is reconfirmed here in Fig. 17. The stationary front was associated with marginally favorable instability parameters compared with that of its immediate environment. The dry air $\sim 10 \mathrm{~km}$ northwest of the dryline had the highest LCL, LFC, and CIN and the lowest CAPE. Again, the roll boundary was associated with the most favorable instability parameters. The large decrease in CAPE and increase in CIN for the last drop is because this particular dropsonde was located at a position where storm C just passed.

The virtual potential temperature in both Figs. 14

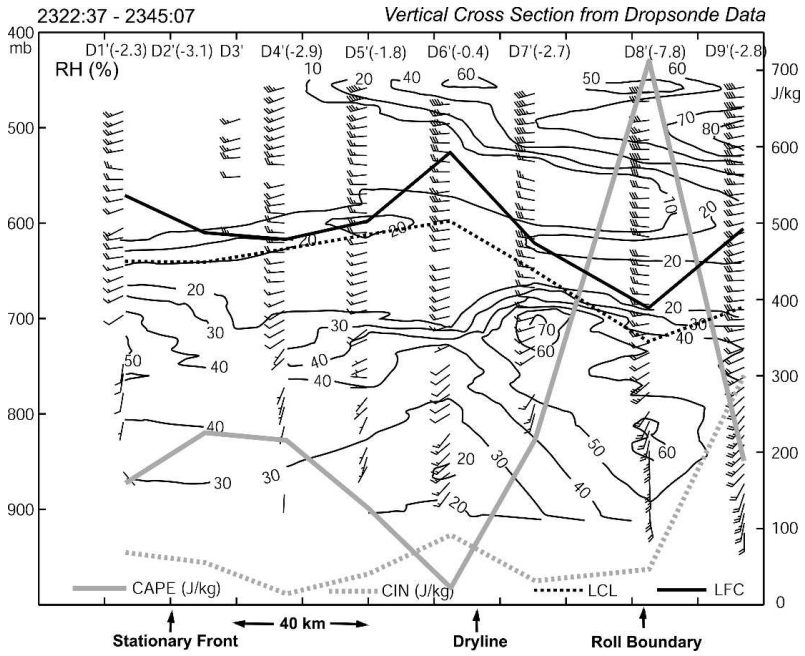

FIG. 17. Same as Fig. 14 except for relative humidity and instability parameters including CAPE, CIN, LI, LCL, and LFC; LI is labeled beside each dropsonde symbol (D1'-D9') at the top of the figure. and 16 suggests there is a $\theta_{\mathrm{v}}$ differential of $\sim 0.5 \mathrm{~K}$ across the dryline, consistent with flight-level data in Fig. 8. Since the most favorable instability parameters as well as stronger surface convergence as indicated by the stronger radar reflectivity fine line was not associated with the dryline itself but with a roll boundary 40-50 km east-southeast of the dryline within the moist air, it is not surprising that convection did not start along the dryline, but instead, along the roll boundary. Only one storm was initiated along the roll boundary (storm $\mathrm{C}$ in Figs. 13b and 13c), which reached a maximum reflectivity of $60 \mathrm{~dB} Z_{\mathrm{e}}$. Various factors that may contribute to "convection initiation failure" near the 11 June 2002 Oklahoma panhandle dryline will be discussed in section 7 .

\section{Environmental conditions detrimental to convection initiation}

The major reason that the dryline is often a favorable place for initiating storms is because it creates the necessary lift and is very close to the moist air that fuels the storm. However, observations frequently suggest that even though the lift from the dryline seems to be adequate and clouds are forming along the dryline, these clouds may fail to develop into storms (Atkins et al. 1998; Weiss and Bluestein 2002). Several hypotheses have been proposed by various researchers in the past to explain the lack of convection initiation along some drylines, and this section will examine them in the context of the 11 June IHOP_2002 dryline.

Some typical soundings on both sides of the dryline from NCAR MGLASS and the Learjet are shown in Figs. 18 and 19, respectively. The positions of these soundings relative to the dryline are shown in Figs. $6 \mathrm{~b}$ and 6f. A pronounced cap inversion is apparent in Fig. 18 and a substantial dry layer can be seen above the well-mixed CBL from 700 to $500 \mathrm{mb}$ on both sides of the dryline. This same feature is also apparent in the Learjet dropsondes as shown in Fig. 19. Weiss and Bluestein (2002) suggested that a dry layer between the LCL and LFC might be the reason why convection did not initiate along a dryline they studied. The dry layer between the LCL and LFC is detrimental to CI because updrafts originating within the CBL tend to evaporate inside this very dry layer and the evaporative cooling will make the updrafts lose their buoyancy.

Storm initiation, organization, and lifetime may be affected by the relative movement of convective clouds and convergence lines (Wilson and Megenhardt 1997). If the clouds do not propagate at approximately the same speed as the boundary, convection may be adversely affected. The cloud lines were moving almost 


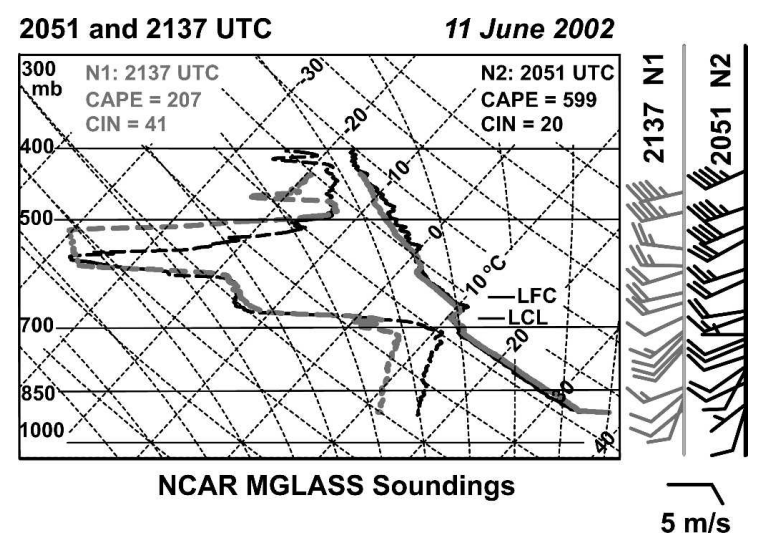

FIG. 18. NCAR MGLASS soundings launched near the dryline at 2051 and 2137 UTC on 11 Jun 2002. The solid and dashed lines represent temperature and dewpoint temperature, respectively. Black (gray) lines indicate the sounding at 2051 (2137) UTC. The positions of these two soundings are plotted in Fig. 6b. The heights of the LCL and LFC for the 2051 UTC sounding are indicated in the figure. Both CAPE and CIN values are in $\mathrm{J} \mathrm{kg}^{-1}$. Vertical profile of the horizontal winds is shown with the half barb, full barb, and flag representing $2.5,5.0$, and $25.0 \mathrm{~m} \mathrm{~s}^{-1}$, respectively.

parallel to the dryline as shown by the satellite imagery movie loops in this case (not shown). Since the dryline was retreating to the northwest at a rather slow speed of $1.5-2.5 \mathrm{~m} \mathrm{~s}^{-1}$, the distance between the dryline and cloud line did not change significantly over the lifetime of the cloud line; therefore, the relative movement of clouds and dryline is not likely the reason why convection initiation did not occur in this case.

Although the temperature inversion around $700 \mathrm{mb}$ was weakening in time, the moisture content at all heights also decreased during the 2100-2330 time period. The drying trend of the whole boundary layer is another factor unfavorable for CI.

By analyzing a dryline case from VORTEX, Richter and Bosart (2002) proposed that an upper-level ridge that was over the dryline region created middle-level subsidence and warming and a strong cap inversion. As a result of the strong inversion, deep convection did not start even though the dryline was initiating clouds. The NCEP-NCAR reanalysis of 500-mb geopotential height and vertical pressure velocity $(\omega)$ covering the IHOP_2002 domain is shown in Fig. 20. Apparently the Oklahoma panhandle where the IHOP_2002 IOR was located was under the influence of middle-level subsidence. The middle-level warming of $\sim 0.4^{\circ} \mathrm{C}$ on the dry side and $\sim 1.2^{\circ} \mathrm{C}$ on the moist side of the dryline over a time period of $\sim 2 \mathrm{~h}$ can be estimated from soundings shown in Fig. 19. The middle-level subsidence could possibly explain why the middle-level clouds advected into this region from southwest disappeared shortly af- (a) 2146 and 2149 UTC

11 June 2002

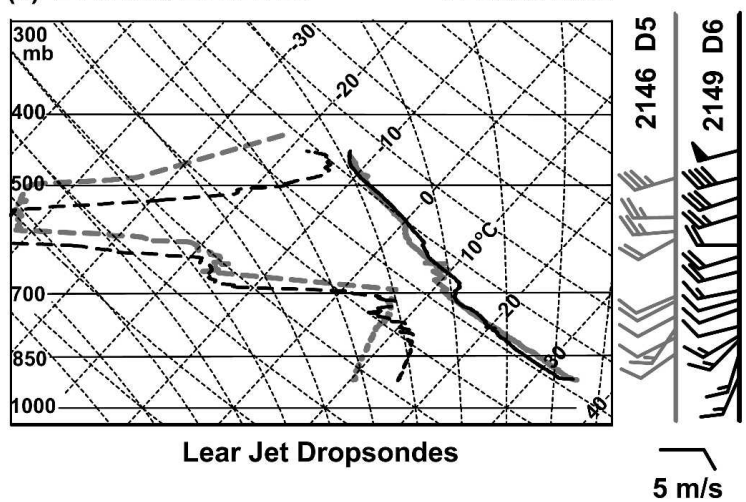

(b) 2334 and 2337 UTC

11 June 2002

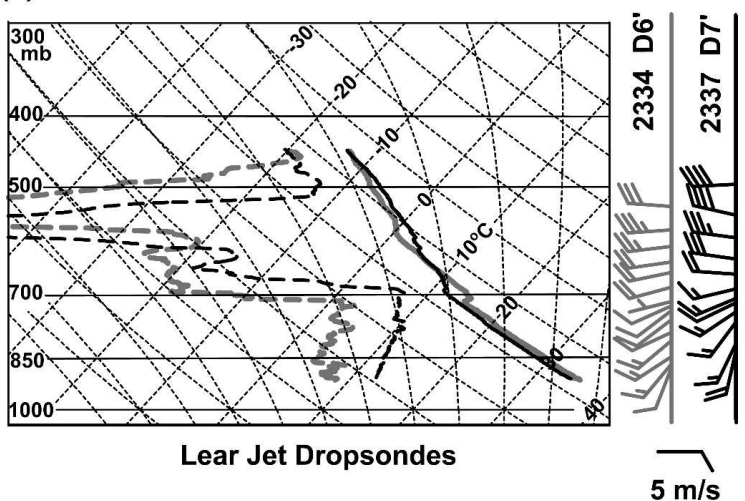

FIG. 19. Learjet dropsondes near the dryline at (a) 2146 (gray) and 2149 UTC (black) and (b) 2334 (gray) and 2337 UTC (black). Solid and dashed lines represent temperature and dewpoint temperature, respectively. The positions of these four soundings are indicated in Figs. 6b and 6f. Vertical profile of the horizontal winds is shown with the half barb, full barb, and flag representing $2.5,5.0$, and $25.0 \mathrm{~m} \mathrm{~s}^{-1}$, respectively.

ter they entered the Oklahoma panhandle. Notice that storm A in Fig. 1 was initiated in a region with middlelevel upward motion. Although middle-level subsidence that promotes middle-level drying and warming and creates strong cap inversion is unfavorable to CI, it does not mean convection will not develop under regions of middle-level subsidence. As long as the mesoscale or convective-scale lift is strong enough and there is sufficient moisture, parcels will reach their LFC. Storm C in Figs. 1d, 13b, and 13c seems to be a good example of a storm initiated under a middle-level subsidence region. On the other hand, storm $\mathrm{C}$ was relatively small and short-lived compared to storm A, perhaps as a result of its being developed under the unfavorable middle-level conditions.

One major objective of IHOP_2002 was to identify how the special dataset collected by field campaigns can be helpful for operational CI forecasting. It appears that high-resolution four-dimensional kinematic and 
(a) 11 June $20021800 Z$

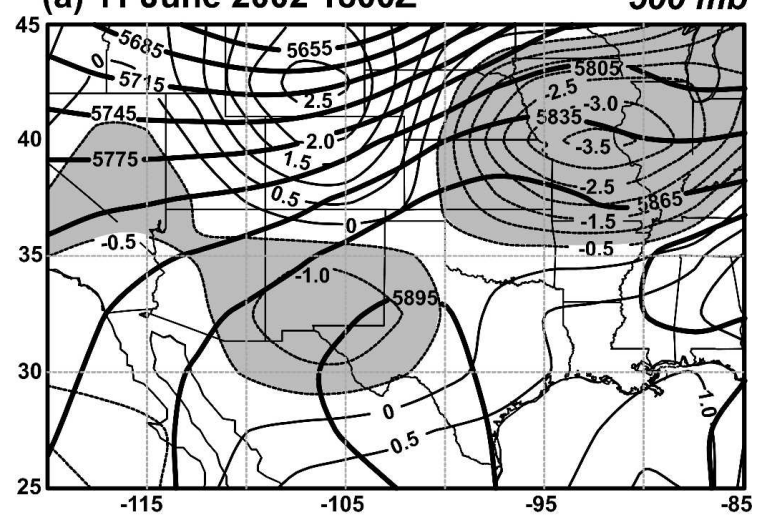

(b) 12 June $20020000 Z$

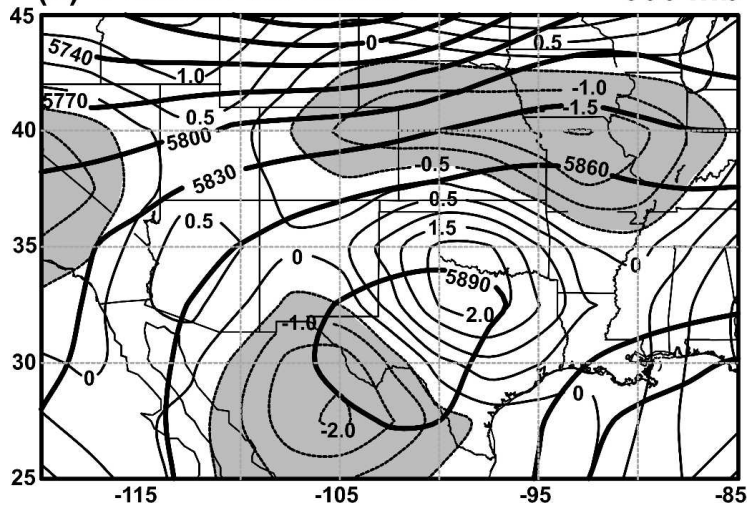

FIG. 20. NCEP-NCAR reanalysis of the $500-\mathrm{mb}$ height and vertical pressure velocity ( $\omega$ ) at (a) 1800 UTC on 11 Jun 2002 and (b) 0000 UTC on 12 Jun 2002. Thick black lines represent geopotential heights with a contour interval of $30 \mathrm{~m}$; thin black lines represent vertical pressure velocity $\omega$ in $10^{-3} \mathrm{hPa} \mathrm{s}^{-1}$ with a contour interval of $0.5 \times 10^{-3} \mathrm{hPa} \mathrm{s}^{-1}$. Upward motion with $\omega<-0.5$ $\times 10^{-3} \mathrm{hPa} \mathrm{s}^{-1}$ is shaded gray.

thermodynamic structures of boundaries are essential for $\mathrm{CI}$ forecasting and it seems that the information needed for accurate CI prediction is still not there even during IHOP_2002. One big gap that has become more apparent through this analysis is the wind fields associated with boundaries whose measurements solely rely on clear-air returns detected by radars. The problem with the clear-air echo is that it tends to disappear above 2-3 km AGL, which causes lack of wind measurements near or above the boundary layer top. As a result of this limited height coverage of the threedimensional wind field, it is almost impossible to know whether or not the boundary layer updrafts reached their LFC. Another deficiency from the observational perspective for $\mathrm{CI}$ forecasting is the four-dimensional water vapor measurements. Although IHOP_2002 was dedicated to filling the gaps in this aspect, detailed fourdimensional water vapor fields are still not available.
What has been achieved in IHOP 2002 are some horizontal and vertical cross sections of the water vapor field. Therefore, the lack of high-resolution threedimensional kinematic and thermodynamic information about updrafts associated with a boundary still presents a great challenge for accurately predicting which pocket(s) of those updrafts will develop into a storm.

\section{Summary and discussions}

On 11 June 2002 during IHOP_2002 a dryline formed over the Oklahoma panhandle as a result of high $\theta_{\mathrm{e}}$ air pushing northwestward toward a stationary front in the warm sector. Convection was expected over the Oklahoma panhandle based on various model runs early in the morning, and an IHOP_2002 IOR was set up near NCAR's S-Pol radar in the Oklahoma panhandle area. The evolution of the dryline's kinematic and thermodynamic structure is documented in this paper by using ELDORA dual-Doppler analysis, S-Pol radar refractivity, LEANDRE II water vapor measurements, Learjet dropsondes, MGLASS soundings, as well as NRL P-3 flight-level data. The dryline was retreating toward the northwest during the intensive observation period from 2100 to 2330 at a speed of $1.5-2.5 \mathrm{~m} \mathrm{~s}^{-1}$ and was associated with a moisture differential of $4-5 \mathrm{~g} \mathrm{~kg}^{-1}$ across a distance of $\sim 4.4-6.6 \mathrm{~km}$. The virtual potential temperature differential across the dryline was relatively weak $(\sim 0.5 \mathrm{~K})$ and pockets of updraft on the order of 2-3 $\mathrm{m} \mathrm{s}^{-1}$ were found near the dryline. Boundary-layerbased clouds were observed along the dryline inside the IHOP_2002 IOR but no deep convection was initiated there. S-Pol radar refractivity shows the greatest moisture gradient slightly northwest of or collocated with the dryline fine line, and a general trend of drying was evident from radar refractivity as well as surface analysis from 2100 to 2330 . LEANDRE II water vapor measurements reveal strong along-line variability in the moisture field near the dryline and suggest that the reflectivity maxima tend to be closely associated with pockets of rising moist air with only a few exceptions. A roll boundary, which has more intense radar reflectivity and a north-south orientation inside the IHOP_2002 IOR from 2100 to 2230, intercepted the dryline near the northeast corner of IHOP_2002 IOR. Interestingly, the interception point that should be a favorable place for CI did not initiate any storm, nor did the dryline itself. Three storms developed in the region on this particular day, and all of them were outside the IHOP_2002 IOR. Storm A, a tornadic one, was initiated near Russell, Kansas ( 200 km northeast of IHOP_2002 IOR), at $\sim 2100$. Another very small storm (storm B) was initiated around 2207 along the stationary front $\sim 100 \mathrm{~km}$ 
north of the IHOP_2002 IOR. The third storm (storm C) was initiated along the roll boundary around 2210 about $80 \mathrm{~km}$ south of the IHOP_2002 IOR.

Middle-level clouds near the dryline were observed by ELDORA along with the dryline itself. These clouds dissipated after they entered the Oklahoma panhandle. The reason for their disappearance is speculated to be the middle-level subsidence shown in the NCEPNCAR reanalysis. The dryline was weakening as seen by ELDORA radar reflectivity, and the boundary layer was drying out according to the S-Pol radar refractivity and soundings. The Learjet dropsonde data show that the most favorable instability parameters were actually associated with the roll boundary, not the dryline. This may explain why storm $\mathrm{C}$ was initiated near the roll boundary at $\sim 2210$. The reasons why the dryline was not able to initiate any storms inside IHOP_2002 IOR were summarized as follows: 1) relatively weak updrafts perhaps as a result of weak baroclinity across the dryline; 2) a substantial dry layer between the LCL and LFC; and 3) strong cap inversion as a result of middlelevel subsidence over the dryline in the Oklahoma panhandle region.

As an "interesting albeit frustrating" null case described by IHOP_2002 nowcasters (E. Szoke, IHOP_2002 field catalog), this dryline provides a unique dataset for examining the differences between what the models predicted and what actually occurred. The reasons why the models overpredicted the convection over the Oklahoma panhandle for this particular case remains to be an interesting research topic for numerical modelers, and the detailed observational study of this case presented by this paper should be very helpful to any numerical simulation of this case. It is also important to note that both the dryline and the roll boundary presented in this study would not be resolved by the conventional observational network if the special datasets from IHOP_2002 were not available. Therefore, if boundaries like this have any impact on CI, accurately forecasting CI would remain to be a great challenge for operational models.

Acknowledgments. The first author is grateful to NCAR's Advanced Study Program and Atmospheric Technology Division for providing necessary support for this research. The comments from two anonymous reviewers greatly improved this manuscript. Thanks are also extended to Drs. Roger Wakimoto and Jim Wilson for their constant encouragements. Dr. Junhong Wang at NCAR provided the dropsonde data. Drs. Roger Wakimoto and Stanley Trier are specially thanked for their insightful reviews of an earlier version of this manuscript.

\section{REFERENCES}

Anthes, R. A., Y. H. Kuo, S. G. Benjamin, and Y. F. Li, 1982: The evolution of the mesoscale environment of severe local storms: Preliminary modeling results. Mon. Wea. Rev., 110, 1185-1213.

Atkins, N. T., R. M. Wakimoto, and C. L. Ziegler, 1998: Observations of the finescale structure of a dryline during VORTEX 95. Mon. Wea. Rev., 126, 525-550.

Barnes, S. L., 1973: Mesoscale objective map analysis using weighted time-series observations. NOAA Tech. Memo. ERL NSSL-62, 60 pp.

Bluestein, H. B., 1993: CLASS for class. Bull. Amer. Meteor. Soc., 74, 1697-1702.

, and C. R. Parks, 1983: A synoptic and photographic climatology of low-precipitation severe thunderstorms in the southern plains. Mon. Wea. Rev., 111, 2034-2046.

— storm formation along the dryline. Mon. Wea. Rev., 121, 1352-1374.

Bruneau, D., P. Quaglia, C. Flamant, M. Meissonnier, and J. Pelon, 2001: Airborne lidar LEANDRE II for water-vapor profiling in the troposphere. Appl. Opt., 40, 3450-3475.

Carbone, R. E., M. J. Carpenter, and C. D. Burghart, 1985: Doppler radar sampling limitations in convective storms. J. Atmos. Oceanic Technol., 2, 357-361.

Crawford, T. M., and H. B. Bluestein, 1997: Characteristics of dryline passage during COPS-91. Mon. Wea. Rev., 125, 463477.

Cressman, G. P., 1959: An operational objective analysis scheme. Mon. Wea. Rev., 87, 367-384.

Dowell, D. C., and H. B. Bluestein, 2002a: The 8 June 1995 McLean, Texas, storm. Part I: Observations of cyclic tornadogenesis. Mon. Wea. Rev., 130, 2626-2648.

— , and _ 2002b: The 8 June 1995 McLean, Texas, storm. Part II: Cyclic tornado formation, maintenance, and dissipation. Mon. Wea. Rev., 130, 2649-2670.

Fabry, F., 2006: The spatial variability of moisture in the boundary layer and its effect of convection initiation: Project-long characterization. Mon. Wea. Rev., 134, 79-91.

- C. Frush, I. Zawadzki, and A. Kilambi, 1997: On the extraction of the near-surface index of refraction using radar phase measurements from ground targets. J. Atmos. Oceanic Technol., 14, 978-987.

Grasso, L. D., 2000: A numerical simulation of dryline sensitivity to soil moisture. Mon. Wea. Rev., 128, 2816-2834.

Hane, C. E., C. L. Ziegler, and H. B. Bluestein, 1993: Investigation of the dryline and convective storms initiated along the dryline: Field experiments during COPS-91. Bull. Amer. Meteor. Soc., 74, 2133-2145.

— B. B. Bluestein, T. M. Crawford, M. E. Baldwin, and R. M. Rabin, 1997: Severe thunderstorm development in relation to along-dryline variability: A case study. Mon. Wea. Rev., 125, 231-251.

, M. E. Baldwin, H. B. Bluestein, T. M. Crawford, and R. M. Rabin, 2001: A case study of severe storm development along a dryline within a synoptically active environment. Part I: Dryline motion and an Eta model forecast. Mon. Wea. Rev., 129, 2183-2204.

, R. M. Rabin, T. M. Crawford, H. B. Bluestein, and M. E. Baldwin, 2002: A case study of severe storm development along a dryline within a synoptically active environment. Part II: Multiple boundaries and convective initiation. Mon. Wea. Rev., 130, 900-920. 
Hildebrand, P. H., C. A. Walther, C. L. Frush, J. Testud, and F. Baudin, 1994: The ELDORA/ASTRAIA airborne Doppler weather radar: Goals, design, and first field tests. Proc. IEEE, 82, 1873-1890.

— , and Coauthors, 1996: The ELDORA/ASTRAIA airborne Doppler weather radar: High resolution observations from TOGA COARE. Bull. Amer. Meteor. Soc., 77, 213-232.

Hock, T. F., and J. L. Franklin, 1999: The NCAR GPS dropwindsonde. Bull. Amer. Meteor. Soc., 80, 407-420.

Kalnay, E., and Coauthors, 1996: The NCEP/NCAR 40-Year Reanalysis Project. Bull. Amer. Meteor. Soc., 77, 437-471.

Kistler, R., and Coauthors, 2001: The NCEP-NCAR 50-year reanalysis: Monthly means CD-ROM and documentation. Bull. Amer. Meteor. Soc., 82, 247-268.

Koch, S. E., and J. McCarthy, 1982: The evolution of an Oklahoma dryline: Part II: Boundary-layer forcing of mesoconvective systems. J. Atmos. Sci., 39, 237-257.

Lee, W.-C., P. Dodge, F. D. Marks, and P. H. Hildebrand, 1994: Mapping of airborne Doppler radar data. J. Atmos. Oceanic Technol., 11, 572-578.

Leise, J. A., 1982: A multidimensional scale-telescoped filter and data extension package. NOAA Tech. Memo. ERL-82, 11 pp. [Available from NOAA ERL, 325 Broadway, Boulder, CO 80303.]

Lutz, J., P. Johnson, B. Lewis, E. Loew, M. Randall, and J. VanAndel, 1995: NCAR's S-Pol: Portable polarimetric Sband radar. Preprints, Ninth Symp. on Meteorological Observations and Instrumentation, Charlotte, NC, Amer. Meteor. Soc., 408-410.

Miller, J. A., T. A. Kovacs, and P. R. Bannon, 2001: A shallow water model of the diurnal dryline. J. Atmos. Sci., 58, 35083524.

Mohr, C. G., L. J. Miller, R. L. Vaughn, and H. W. Frank, 1986: The merger of mesoscale datasets into a common Cartesian format for efficient and systematic analysis. J. Atmos. Oceanic Technol., 3, 146-161.

Murphey, H. V., R. M. Wakimoto, C. Flamant, and D. E. Kingsmill, 2006: Dryline on 19 June 2002 during IHOP. Part I: Airborne Doppler and LEANDRE II analysis of the thin line structure and convection initiation. Mon. Wea. Rev., 134, 406-430.

NSSP Staff, 1963: Environmental and thunderstorm structures as shown by National Severe Storms Project observations in spring 1960 and 1961. Mon. Wea. Rev., 91, 271-292.

Oye, R., C. Mueller, and S. Smith, 1995: Software for radar translation, visualization, editing, and interpolation. Preprints, 27th Conf. on Radar Meteorology, Vail, CO, Amer. Meteor. Soc., 359-361.

Parsons, D. B., M. A. Shapiro, R. M. Hardesty, R. J. Zamora, and J. M. Intrieri, 1991: The finescale structure of a west Texas dryline. Mon. Wea. Rev., 119, 1242-1258.

- , - , and E. Miller, 2000: The mesoscale structure of a nocturnal dryline and of a frontal-dryline merger. Mon. Wea. Rev., 128, 3824-3838.

Peckham, S. E., and L. J. Wicker, 2000: The influence of topography and lower tropospheric winds on dryline morphology. Mon. Wea. Rev., 128, 2165-2189.
Rhea, J. O., 1966: A study of thunderstorm formation along drylines. J. Appl. Meteor., 5, 58-63.

Richter, H., and L. F. Bosart, 2002: The suppression of deep moist convection near the southern Great Plains dryline. Mon. Wea. Rev., 130, 1665-1691.

Schaefer, J. T., 1974: The lifecycle of the dryline. J. Appl. Meteor., 13, 444-449.

, 1986: The dryline. Mesoscale Meteorology and Forecasting, P. S. Ray, Ed., Amer. Meteor. Soc., 549-572.

Shaw, B. L., R. A. Pielke, and C. L. Ziegler, 1997: A threedimensional numerical simulation of a Great Plains dryline. Mon. Wea. Rev., 125, 1489-1506.

Testud, J., P. H. Hildebrand, and W.-C. Lee, 1995: A procedure to correct airborne Doppler radar data for navigation errors using the echo returned from the earth's surface. J. Atmos. Oceanic Technol., 12, 800-820.

Trier, S. B., F. Chen, and K. W. Manning, 2004: A study of convection initiation in a mesoscale model using high-resolution land surface initial conditions. Mon. Wea. Rev., 132, 29542976.

Sun, W.-Y., and C.-C. Wu, 1992: Formation and diurnal variation of the dryline. J. Atmos. Sci., 49, 1606-1619.

Wakimoto, R. M., and H. Cai, 2000: Analysis of a nontornadic storm during VORTEX 95. Mon. Wea. Rev., 128, 565-592.

— and - 2002: Airborne observations of a front near a col during FASTEX. Mon. Wea. Rev., 130, 1898-1912.

_ C. Liu, and H. Cai, 1998: The Garden City, Kansas, storm during VORTEX 95: Part I: Overview of the storm's life cycle and mesocyclogenesis. Mon. Wea. Rev., 126, 372-392.

- W.-C. Lee, H. B. Bluestein, C.-H. Liu, and P. H. Hildebrand, 1996: ELDORA observations during VORTEX 95. Bull. Amer. Meteor. Soc., 77, 1465-1481.

Weckwerth, T. M., and Coauthors, 2004: An overview of the International $\mathrm{H}_{2} \mathrm{O}$ Project (IHOP_2002) and some preliminary highlights. Bull. Amer. Meteor. Soc., 85, 253-277.

- R. P. Crystalyne, F. Fabry, S. Park, and J. W. Wilson, 2005: Radar refractivity retrieval: Validation and application to short-term forecasting. J. Appl. Meteor., 44, 285-300.

Weiss, C. C., and H. B. Bluestein, 2002: Airborne pseudo-dual Doppler analysis of a dryline-outflow boundary intersection. Mon. Wea. Rev., 130, 1207-1226.

Wilson, J. W., and D. L. Megenhardt, 1997: Thunderstorm initiation, organization, and lifetime associated with Florida boundary layer convergence lines. Mon. Wea. Rev., 125, $1507-1525$.

_ , T. M. Weckwerth, J. Vivekanandan, R. M. Wakimoto, and R. W. Russell, 1994: Boundary layer clear-air radar echoes: Origin of echoes and accuracy of derived winds. J. Atmos. Oceanic Technol., 11, 1184-1206.

Ziegler, C. L., and C. E. Hane, 1993: An observational study of the dryline. Mon. Wea. Rev., 121, 1134-1151.

, and E. N. Rasmussen, 1998: The initiation of moist convection at the dryline: Forecasting issues from a case study perspective. Wea. Forecasting, 13, 1106-1131.

, W. J. Martin, R. A. Pielke, and R. L. Walko, 1995: A modeling study of the dryline. J. Atmos. Sci., 52, 273-285. 